Portland State University

PDXScholar

8-6-1982

\title{
Aspects of Anuran Metabolism: Effects of Chronic Hypoxia on Maximal Oxygen Uptake Rates and the Fate of Lactic Acid
}

Thomas Charles Solberg

Portland State University

Follow this and additional works at: https://pdxscholar.library.pdx.edu/open_access_etds

Part of the Biochemical Phenomena, Metabolism, and Nutrition Commons, and the Physiology Commons

Let us know how access to this document benefits you.

\section{Recommended Citation}

Solberg, Thomas Charles, "Aspects of Anuran Metabolism: Effects of Chronic Hypoxia on Maximal Oxygen Uptake Rates and the Fate of Lactic Acid" (1982). Dissertations and Theses. Paper 3225.

https://doi.org/10.15760/etd.3215

This Thesis is brought to you for free and open access. It has been accepted for inclusion in Dissertations and Theses by an authorized administrator of PDXScholar. Please contact us if we can make this document more accessible: pdxscholar@pdx.edu. 
AN ABSTRACT OF THE THESIS OF Thomas Charles Solberg for the Master of Science in Biology presented August 6, 1982.

Title: Aspects of Anuran Metabolism: Effects of Chronic Hypoxia on Maximal Oxygen Uptake Rates and the Fate of Lactic Acid

APPROVED BY MEMBERS OF THE THESIS COMMITTEE:

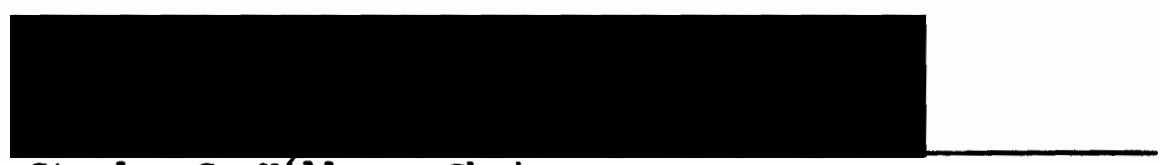

Stanley S. HLllman, Chairman

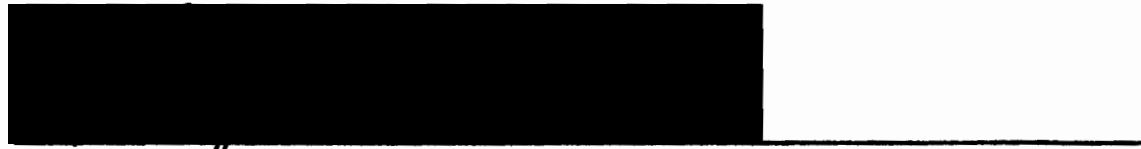

Philip C./Withers

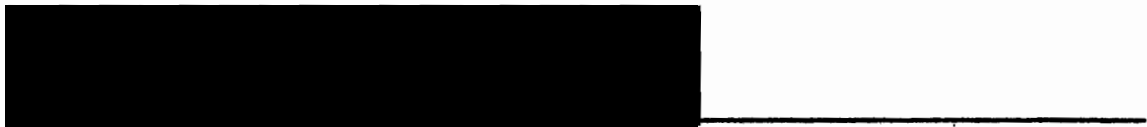

Richard B. Forbes

Some aspects of anuran metabolism are examined, with special emphasis on possible limitations to aerobic metabolism and the effect of chronic hypoxia acclimation on maximal rates of aerobic metabolism and the metabolic fate of lactic acid accumulated after anaerobic metabolism.

During exposure to hypoxia, oxygen delivery could possibly impose a limit on maximal rates of oxygen consumption $\left(\dot{\mathrm{V}}_{2}, \max \right)$. The $\dot{\mathrm{V}}_{2}, \max$ in Xenopus Zaevis did not decrease with a decline in ambient $\mathrm{PO}_{2}$ to 100 torr. At $\mathrm{P}_{2}$ less than 100 torr, $\dot{\mathrm{V}}_{\mathrm{O}_{2}}$, max declined and 
was highly correlated with ambient $\mathrm{P}_{2}$.

Chronic hypoxia acclimation increased the blood oxygen capacity of Xenopus laevis, due mainly to polycythemia. There was no increase in $\dot{\mathrm{V}}_{2}$, max after hypoxic acclimation except at the lowest $\mathrm{PO}_{2}$ tested $\left(\mathrm{PO}_{2}\right.$ less than 38 torr).

The fate of lactic acid accumulated after activity was examined in Bufo anericanus, Rana pipiens and Xenopus Zaevis using $c^{14}$-labelled lactic acid. Less than 58 of the $c^{14}$ activity appeared as expired $\mathrm{C}^{14} \mathrm{O}_{2}$ in all animals. Rana pipiens accumulated large amounts of the $c^{14}$ activity in the muscles. $c^{14}$ activity in Bufo americanus was more evenly distributed throughout many tissues, with the highest concentrations in the blood, liver, lungs and ventricle. 


\begin{abstract}
ASPECTS OF ANURAN METABOLISM:
EFFECTS OF CHRONIC HYPOXIA ON MAXIMAL

OXYGEN UPTAKE RATES AND THE FATE OF LACTIC ACID
\end{abstract}

by

THOMAS CHARLES SOLBERG

A thesis submitted in partial fulfillment of the requirements for the degree of

\author{
MASTER OF SCIENCE \\ in \\ BIOLOGY
}

Portland State University

1982 
TO THE OFFICE OF GRADUATE STUDIES AND RESEARCH:

The members of the Committee approve the thesis of Thomas Charles Solberg presented August 6, 1982 .

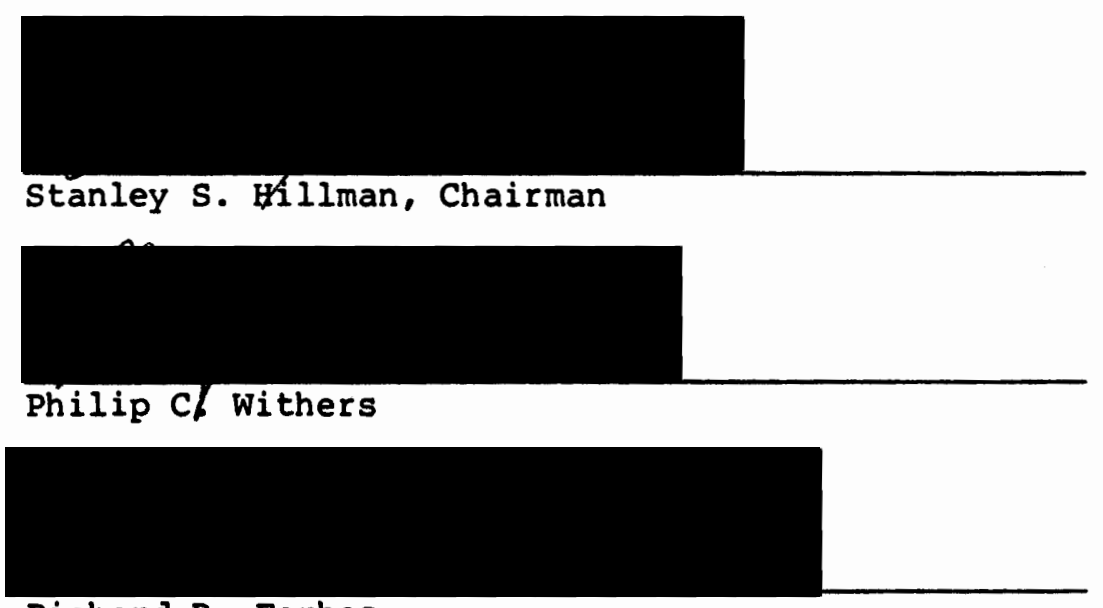

Richard B. Forbes

\section{APPROVED:}

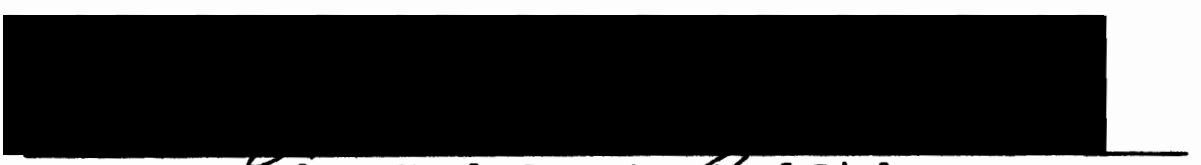

W. Herman Taylor, Head, Departmert of Biology

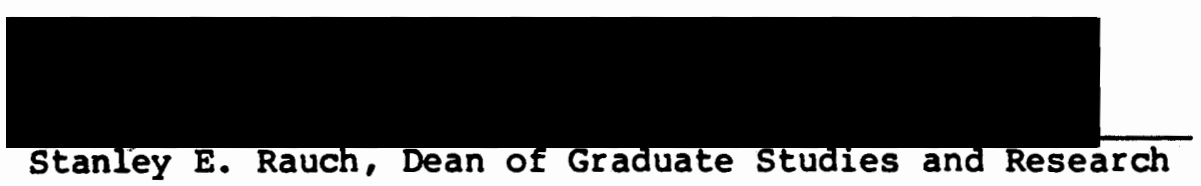




\section{ACKNOWLEDGEMENTS}

A special debt of gratitude is owed Drs. Stan Hillman and Phil Withers. Their advice, support and patience made this thesis possible, if not inevitable. Their friendship and guidance will not soon be forgotten.

My colleagues, the biology graduate students of Portland state, especially Scott Landrey, James Campbell and Nancy Broshot (the old timers) made this experience much more rewarding and enjoyable.

My parents made it all possible. Their support in all of my endeavors, especially the ones they didn't fully understand, was unwavering and greatly appreciated.

Special thanks to my wife, Mitch, who made it all bearable and worthwhile. When no light was at the end of the tunnel, she lead the way •

May we all meet at the Fog on Friday. 
TABLE OF CONTENTS

PAGE

ACKNOWLEDGEMENTS . . . . . . . . . . . . . . . . . . .

LIST OF TABLES

vi

LIST OF FIGURES

vi i

INTRODUCTION

CHAPTER I

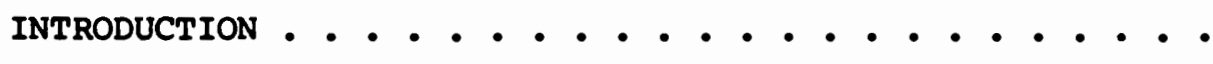

MATERIALS AND METHODS

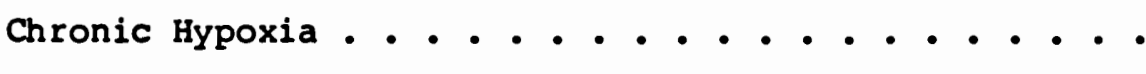

Maximal Oxygen Consumption . . . . . . . . . .

Hematology and Morphology . . . . . . . . . .

Maximal Oxygen Consumption $\left(\dot{\mathrm{V}}_{\mathrm{O}_{2}}, \max \right) \ldots . . . . . .$.

Hematology and Morphology . . . . . . . . . . .

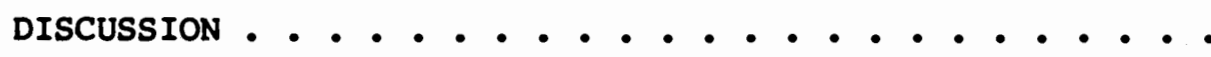

Hematology and Morphology . . . . . . . . . . .

CHAPTER II

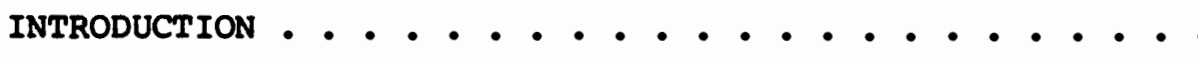

MATERIALS AND METHODS . . . . . . . . . . . . .

Lactate Removal Rate and Oxygen Consumption During

Recovery . . . . . . . . . . . . . . . 
PAGE

Fate of $c^{14}$-Lactate ................. 24 RESULTS . . . . . . . . . . . . . . . 25

Oxygen Consumption Rates and Lactate Concentrations During Recovery . . . . . . . . . . . . 25

Fate of Lactic Acid . . . . . . . . . . . 26

DISCUSSION . . . . . . . . . . . . . . . . 27

Oxygen Consumption Rates and Lactate Disappearance During Recovery ................ . 27

Fate of Lactic Acid . . . . . . . . . . . 27 REFERENCES . . . . . . . . . . . . . . . . . . . . . 42 42 APPENDIX A . . . . . . . . . . . . . . . . . . . 47 


\section{LIST OF TABLES}

TABLE

PAGE

I Hematological Parameters for Control and 100 Torr

Chronic Hypoxia Acclimated Xenopus Zaevis. Values are Mean \pm Standard Error. Asterisk indicates

Significant Difference $(P<0.025)$. . . . . . .

II The Fate of Lactic Acid in Some Anuran Amphibians.

Values are Mean \pm Standard Error for Rana pipiens

$(n=4)$ and Bufo americanus $(n=4)$. Values for Xenopus

Zaevis for 4 Hour $(n=2)$ and 8 Hour $(n=2)$ Recovery are

Means. . . . . . . . . . . . . . . . 
IIST OF FIGURES

FIGURE

PAGE

1. Summary of the aerobic and anaerobic metabolic pathways in the catabolism of glucose, stressing energetic requirements and yields. . . . . . . . . . . . .

2. Maximal oxygen consumption rates $\left(\dot{\mathrm{V}}_{\mathrm{O}_{2}}, \max \right)$ in $\mathrm{ml} \mathrm{O}_{2} \cdot \mathrm{g}^{-\mathrm{I}_{\mathrm{hr}}}{ }^{-1}$ versus $\mathrm{P}_{2}$ in torrs for chronic hypoxia acclimated and control Xenopus Zaevis. Points are means, horizontal and vertical lines are two standard errors. . . . . . . .

3. The $\dot{\mathrm{V}}_{\mathrm{O}_{2}}, \max \left(\mathrm{ml} \mathrm{O}_{2} \cdot \mathrm{g}^{-1} \mathrm{hr}{ }^{-1}\right)$ versus ambient $\mathrm{P}_{\mathrm{O}_{2}}$. Graph shows mean values obtained in this paper (horizontal and vertical bars are two standard errors) and the predicted values (x) of Withers and Hillman (1982a). . . . . . .

4. The rate of oxygen consumption ( $\mathrm{ml} \mathrm{O}_{2} \cdot \mathrm{g}^{-1} \mathrm{hr} \mathrm{r}^{-1}$ ) during recovery from exhaustive exercise versus time of recovery.

5. Whole body lactate concentrations $\left(\mathrm{mg}^{\circ} 100 \mathrm{ml}^{-1}\right)$ during recovery from exhaustive exercise versus time of recovery (in minutes) ........................

6. The percentage of $\mathrm{C}^{14}$ label injected (8DPM) recovered as expired $\mathrm{C}^{14} \mathrm{O}_{2}$ versus time of recovery (hours) for Rana pipiens. . . . . . . . . . . . . . . . . . .

7. The percentage of $\mathrm{C}^{14}$ label injected (8DPM) recovered as expired $\mathrm{C}^{14} \mathrm{O}_{2}$ versus time of recovery (hours) for Bufo americanus....................... 


\section{INTRODUCTION}

Ectothermic vertebrates rely to a large extent upon anaerobic metabolism during high levels of activity (Bennett and Licht, 1973; Hutchison and Turney, 1975; Bennett, 1978). The extent of the anaerobic contribution to activity metabolism has been extensively studied (Bennett and Licht, 1973; Hutchison et al., 1977; Hutchison and Miller, 1979b) but these experiments used electrical shock to induce activity, and manometric techniques for the measurement of oxygen consumption. Manometric methods seriously underestimate oxygen consumption due to electrolytic gas generation and temperature transients in the manometer chamber (Hillman et al.. 1979). Electrical stimulation may also cause excessive production of muscle lactic acid and decreased blood lactic acid levels during activity due to circulatory impairment (Putnam, 1979; Hillman et al., 1979).

Glycogen, the polymeric storage form of glucose, is catabolized to pyruvate by the metabolic process known as glycolysis. Pyruvate is then the substrate for oxidation to carbon dioxide and water by the tricarboxylic acid cycle and the mitochondrial electron transport system. This complete oxidation of glucose yields a net 36 ATP per molecule of glucose (Lehninger, 1975). When oxygen is unavailable, the pyruvate formed from glycolysis may be catalysed by lactate dehydrogenase to form lactic acid, with a net yield of two ATP per glucose molecule. This conversion step from pyruvate to lactate is 
important because it regenerates $\mathrm{NAD}^{+}$from $\mathrm{NADH}$ formed in an earlier step in glycolysis (see Figure 1).

There are both advantages and disadvantages to aerobic and anaerobic metabolism. Anaerobic metabolism is much faster than aerobic metabolism since oxygen is not needed by the tissue. Consequently, there is no time lag involved in increasing oxygen transport (i.e. ventilation and the circulation of blood). Anaerobic metabolism is, therefore, very important in burst activity such as escape from predation (Bennett and Licht, 1974). Anaerobic metabolism is less dependent on temperature than aerobic metabolism (Bennett, 1978; Carey, 1979a; Hochachka, 1980; Putnam and Bennett, 1981). This is especially important for ectotherms such as amphibians. The net yield of only two ATP per glucose molecule by anaerobic metabolism, as compared to 36 ATP produced aerobically indicates a relative inefficiency of anaerobic metabolism. Other limitations include the accumulation of potentially toxic lactic acid and the associated $\mathrm{pH}$ effects (metabolic acidosis), and the requirement of anaerobiosis of glucose as its substrate; aerobic metabolism can utilize lipids and proteins as well as glucose.

Anuran amphibians provide an excellent model system for the study of anaerobic and aerobic metabolism due to the considerable interspecific differences in methods of energy generation. Rana pipiens and Rana catesbeiana, for example, rely mainly an anaerobic metabolism during bursts of activity; they have a low maximal rate of oxygen consumption $\left(\dot{\mathrm{V}}_{2}, \max \right)$ and high lactate concentrations during activity (Bennett and Licht, 1974; Hutchison and Turney, 1975; 
Hillman, 1976; Hillman et al., 1979; Hillman and Withers, 1979; Hutchison and Miller, 1979a; Putnam, 1979a). Other anurans such as Bufo cognatus and Bufo boreas have a much higher $\dot{\mathrm{V}}_{\mathrm{O}_{2}}$, $\max$ and lower lactate concentrations during activity (Bennett and Iicht, 1974; Hillman, 1976; Hillman and withers, 1979; Carey, 1979b; Putnam, 1979a). It has been hypothesized that this apparent dichotomy in metabolic "strategies" is associated with predator avoidance mechanisms (Bennett and Licht, 1974). The more-anaerobic anurans depend on rapid, usually saltatory, movements to escape from predators, whereas the more-aerobic species use static defense mechanisms such as lung inflation or skin poisons. There are, however, many species that do not readily fit into either the predominantly aerobic or anaerobic modes. Xenopus Zaevis is an example of an anuran with both a high $\dot{\mathrm{V}}_{2}, \max$ and high lactate concentrations during activity (Hillman, 1976; Hillman and Withers, 1979; Putnam, 1979b).

Taigen et al. (1982), in a survey of a wide variety or anurans, have found a continuum of metabolic strategies rather than a dichotomy. They suggest that since metabolism is a conservative evolutionary feature, the examples found on the extremes of the continuum are responding, by way of adaptation, to a wide variety of morphological, behavioral and ecological pressures and not just predatory pressures.

Nevertheless, anuran amphibians provide an excellent model system for the study of aerobic and anaerobic metabolism since individual species can be examined that depend primarily on one mode 
of energy generation or the other.

The purpose of this research is to examine some aspects of aerobic and anaerobic metabolism in anurans. Chapter I deals with aerobic metabolism; specifically, the hypoxic limit to $\dot{\mathrm{v}}_{2}, \max$ in Xenopus Zaevis. Hypobaric hypoxia was used to examine the physiology of oxygen delivery, especially to determine if diffusion of oxygen from the pulmonary air to the alveolar capillaries is a limitation to $\dot{\mathrm{V}}_{2}$, max. Also in Chapter $\mathrm{I}$ is an examination of the effects of chronic hypoxic acclimation on $\dot{\mathrm{V}}_{2}, \max$ and several hematological and morphological parameters. Chapter II is an examination of the fate of $\mathrm{c}^{14}$-labelled lactic acid in three species of anurans. Rana pipiens is a primarily anaerobic frog, Bufo omericanus is a primarily aerobic toad and Xenopus laevis is intermediate in metabolic strategies, with a high $\dot{\mathrm{V}}_{2}$, $\max$ and high lactate concentrations following exercise. 
Figure 1.

Summary of the aerobic and anaerobic metabolic pathways in the catabolism of glucose, stressing energetic requirements and yields. 

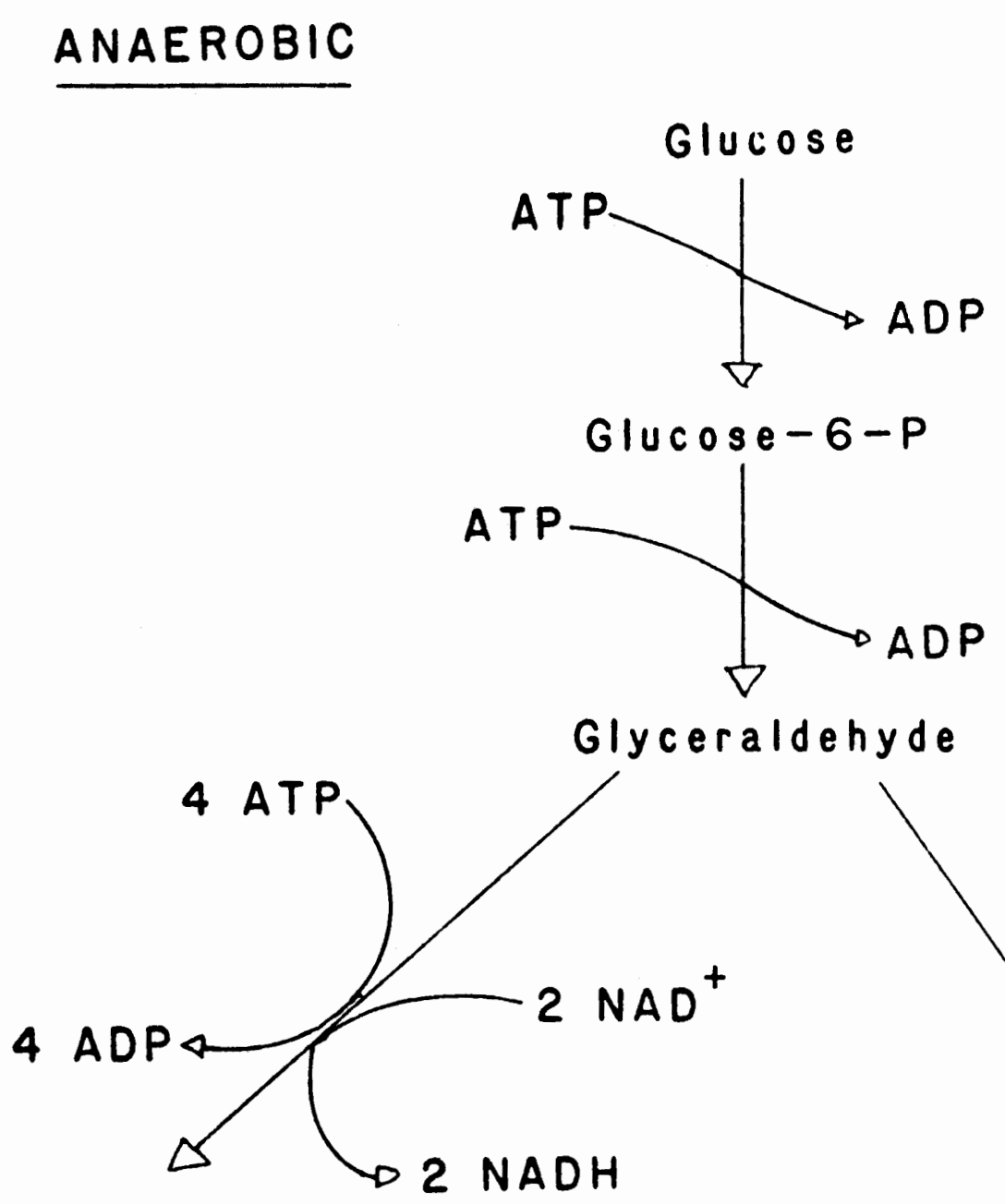

Pyruvate
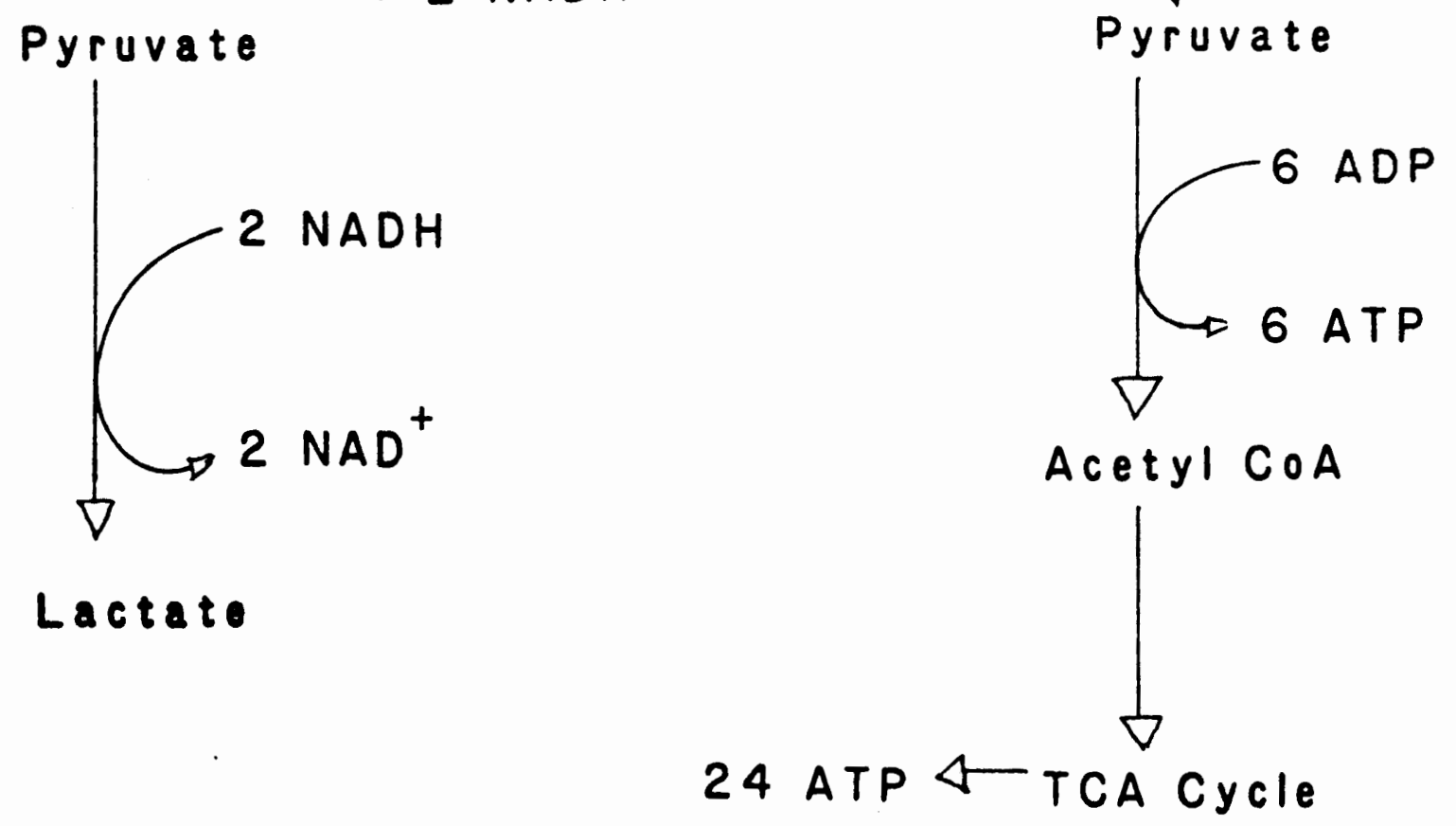

Lactato

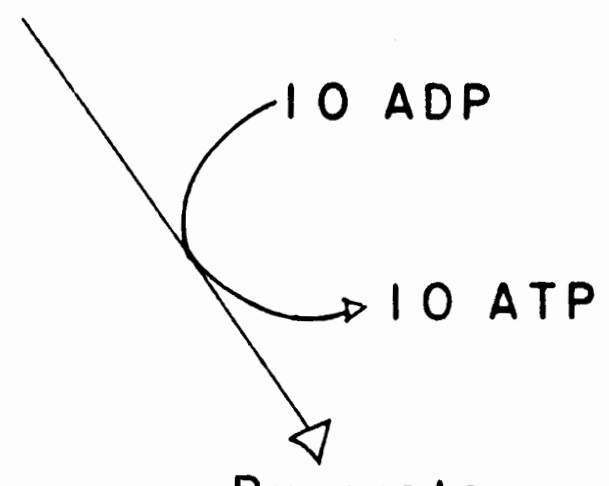

Acetyl CoA 
CHAPTER I

INTRODUCTION

Oxygen availability can be potentially reduced in aquatic environments, during periods of submergence in hypoxic waters, when burrowed or at high altitudes. Some physiological effects of hypoxia on amphibians have been studied, including effects on heart rate and degree of dilation in cutaneous and skeletal muscle capillaries (Armentrout and Rose, 1971), respiratory patterns (Boutilier and Towes, 1977), and metabolic responses such as lactate levels, liver glycogen levels, and blood sugar (Armentrout and Rose, 1971; Jones and Mustafa, 1973). These studies were concerned with the effect of hypoxia on resting oxygen consumption and did not address its effect on maximal rates of oxygen consumption. They were also concerned only with the effects of acute hypoxia (or anoxia), i.e. exposures were less than one day.

Maximal oxygen consumption $\left(\dot{\mathrm{V}}_{\mathrm{O}_{2}}\right.$, max) should be more affected by hypoxia than resting oxygen consumption since availability of oxygen may become rate limiting for maximum aerobic metabolism at a higher critical oxygen tension. Withers (1980) has demonstrated this higher critical oxygen tension for $\dot{\mathrm{V}}_{\mathrm{O}_{2}}$, $\max$ than $\dot{\mathrm{V}}_{\mathrm{O}_{2}}$, rest in lungless salamanders. The critical oxygen tension will be equal to ambient oxygen tension if maximal oxygen consumption is normally limited by the rate of transport of oxygen from pulmonary air to blood, i.e. 
$\dot{\mathrm{V}}_{2}, \max$ would decrease with a decline in oxygen tension. This first diffusive step of oxygen delivery is dependent on the diffusion gradient (i.e. oxygen tension of pulmonary air to blood) and the diffusive capacity. Hillman and withers (1979) have concluded that respiratory surface area, "does not impose a maximum limit on gas exchange in anuran amphibians".

Hematological parameters such as hematocrit and hemoglobin concentration are known to increase during chronic hypoxic exposure. Ventricle and lung size could increase in chronic hypoxia in order to increase oxygen delivery. Increases in these parameters should also serve to increase $\dot{\mathrm{v}}_{\mathrm{O}_{2}}, \max$.

This investigation is the first study to evaluate the effects of hypoxia on $\mathrm{V}_{2}$, max in anuran amphibians and attempts to induce physiological adaptations to chronic hypoxia in Xenopus Zaevis by exposing them to decreased oxygen tensions for a period of two weeks. After this period of acclimation, $\mathrm{V}_{\mathrm{O}_{2}}, \max$ and several hematological and morphological parameters were measured.

\section{MATERIALS AND METHODS}

\section{Chronic Hypoxia}

A group of eight frogs was acclimated for two weeks at a barometric pressure of 500 torr (ambient $\mathrm{P}_{\mathrm{O}_{2}}=100$ torr). The $\dot{\mathrm{V}}_{2}$, $\max$ was measured (see below) for this group after acclimation and compared to a control group. The acclimated group was then further exposed for two weeks to barometric pressures of 100 torr (ambient $\mathrm{P}_{\mathrm{O}_{2}}=20$ torr). Acclimation was accomplished by placing two frogs in each of four 
Nalgene seven liter desiccators containing one liter of water. The desiccators were evacuated to the desired pressure (500 or 100 torr). Controls were placed in screened plastic containers with two animals each in one liter of water. All animals were kept in the dark and the air flushed and low pressure restored daily for two weeks.

It can be calculated that the frogs used approximately 608 of the available $\mathrm{O}_{2}$ in 24 hours at the acclimation pressure of 100 torr, given a standard $\dot{\mathrm{v}}_{2}$ of $0.1 \mathrm{ml} \mathrm{O}{ }_{2} \cdot \mathrm{g}^{-1} \mathrm{hr}^{-1}$ (Hillman and Withers, 1979). The level of hypoxic stress was, therefore, actually less than 100 torr.

\section{Maximal Oxygen Consumption}

The $\dot{\mathrm{V}}_{\mathrm{O}_{2}}, \max$ was determined by the method previously described by Seymour (1973) and Hillman (1976). The procedure consists of placing the animal in a closed metabolic chamber (volume $=450 \mathrm{ml}$ ) and evacuating the chamber to the desired experimental $\mathrm{PO}_{2}$. The chamber was then manually rotated to flip the animal on its dorsum, thereby constantly eliciting the righting reflex. A 15 to $20 \mathrm{ml}$ air sample was withdrawn into a $50 \mathrm{ml}$ syringe after an activity bout of 5 minutes; $\mathrm{CO}_{2}$ and water vapor removed with Ascarite and Drierite, respectively and oxygen content determined with a Beckman OM-14 polarographic oxygen analyser. Temperature of acclimation and activity was $19^{\circ} \mathrm{C}$.

Hematology and Morphology

Hematological and morphological values were measured for the 100 torr acclimated and control Xenopus Zaevis. The animals were pithed, ventricle and lungs removed, blotted dry and weighed to the 
nearest $0.1 \mathrm{mg}$. A blood sample was taken from the ventricle in a heparinized capillary tube which was centrifuged at 3400 RPM for 5 minutes. Hematocrit is the percent packed red cells. Hemoglobin content was determined by the cyanomethemoglobin method and red blood cell count was measured on a Coulter counter model $\mathrm{Z}_{\mathrm{BI}}$ Mean cell volume (MCV), mean cell hemoglobin (MCH) and mean cell hemoglobin concentration (MCHC) were determined as:

$$
\begin{aligned}
M C V & =\frac{\text { Hematocrit }(z) \times 10}{\text { RBC count (in millions) }} \\
M C H & =\frac{\text { Hemoglobin }\left(g \cdot 100 \mathrm{ml}^{-1}\right) \times 10}{\text { RBC count }(\text { in millions) }} \\
M C H C & =\frac{\text { Hemoglobin }\left(g \cdot 100 \mathrm{ml}^{-1}\right) \times 100}{\text { Hematocrit }(8)}
\end{aligned}
$$

RESULTS

\section{Maximal Oxygen Consumption $\left(\dot{\mathrm{V}}_{2}\right.$, max)}

The effect of hypoxia on $\dot{\mathrm{V}}_{2}, \max$ in control and chronically acclimated Xenopus Zaevis is shown in Figure 2. The $\dot{\mathrm{V}}_{2}, \max$ was $1.10 \pm$ se $0.07 \mathrm{ml} \mathrm{O}{ }_{2} \cdot g^{-1} \mathrm{hr}^{-1}(\mathrm{n}=15)$ at normal ambient $\mathrm{P}_{\mathrm{O}_{2}}$ of 159 torr and was independent of ambient $\mathrm{P}_{2}$ above approximately 100 torr. The $\dot{\mathrm{v}}_{\mathrm{O}_{2}}, \max$ was $1.05 \pm 0.045 \mathrm{ml} \mathrm{O} \mathrm{O}_{2} \cdot \mathrm{g}^{-1} \mathrm{hr}^{-1}(\mathrm{n}=36)$ for all frogs at $\mathrm{P}_{2}$ above the critical $\mathrm{P}_{2}$ of 100 torr. The $\dot{\mathrm{V}}_{\mathrm{O}_{2}}$, max decreased significantly at $\mathrm{P}_{2}$ less than 100 torr and was highly correlated with ambient $\mathrm{P}_{\mathrm{O}_{2}} ; \dot{\mathrm{V}}_{\mathrm{O}_{2}}, \max =0.084( \pm$ se 0.050$)+0.0023( \pm$ se 0.00017$)$ 


\section{Figure 2.}

Maximal oxygen consumption rates $\left(\dot{\mathrm{v}}_{\mathrm{O}_{2}}, \max \right)$ in $\mathrm{ml} \mathrm{O}_{2} \cdot \mathrm{g}^{-1} \mathrm{hr}^{-1}$ versus $\mathrm{PO}_{2}$ in torr for chronic hypoxia acclimated and control Xenopus Zaevis. Points are means, horizontal and vertical lines are two standard errors. 

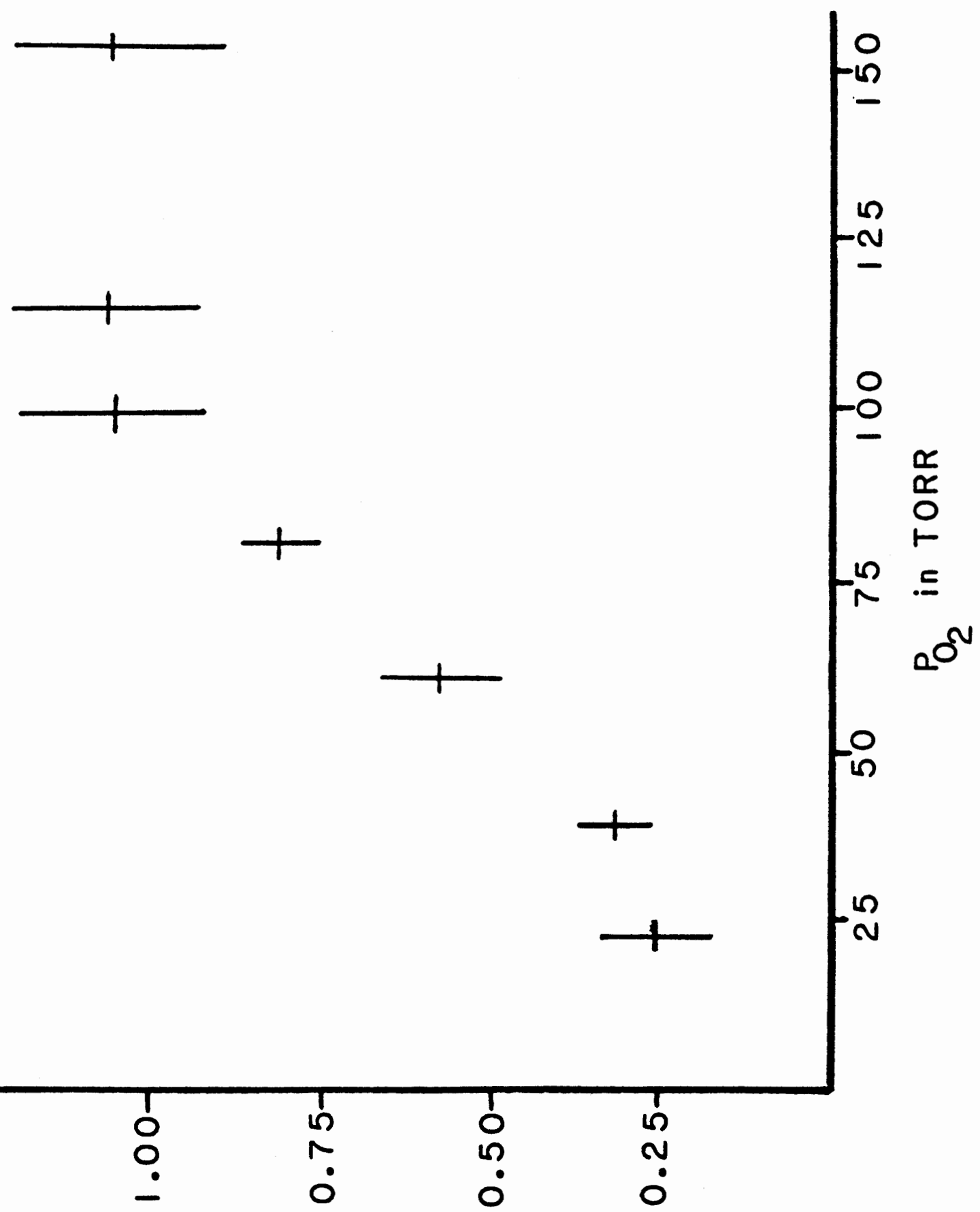

$$
1-34_{1-6}{ }^{2} \text { Olw u! xew. }{ }^{2} 0 \text { }
$$


$x \mathrm{P}_{2}\left(r^{2}=0.79 ; n=51\right)$. Two animals died in the 100 torr acclimation period.

Hematology and Morphology

The effect of chronic hypoxia on hematological parameters is shown in Table I. There was a significant increase in RBC count, hematocrit, hemoglobin and $\mathrm{MCH}$ but no significant change in $\mathrm{MCV}$ or MCHC. There was no significant difference in ventricle mass or lung mass for the two groups.

\section{DISCUSSION}

The $\dot{\mathrm{V}}_{\mathrm{O}_{2}}$, max measured for Xenopus Zaevis at ambient $\mathrm{P}_{\mathrm{O}_{2}}$ of 100159 torr $\left(1.05 \pm\right.$ se $\left.0.045 \mathrm{ml} \mathrm{O}{ }_{2} \cdot \mathrm{g}^{-1} \mathrm{hr}^{-1}\right)$ is in general agreement with that of Hillman and withers (1979) and is approximately ten times resting $\dot{\mathrm{V}}_{2}$ for Xenopus Zaevis (Hillman and withers, 1979). The $\dot{\mathrm{V}}_{2}$, $\max$ declined at $\mathrm{P}_{\mathrm{O}_{2}}$ less than 100 torr. Therefore, the critical oxygen tension $\left(P_{C}\right)$ for $\dot{\mathrm{V}}_{2}$, max in Xenopus Zaevis is about 100 torr. A similar $\mathrm{P}_{2}$ dependence has been determined for plethodontid salamanders by withers (1980) in which the critical $\mathrm{P}_{2}$ was 110 torr, for Bufo cognatus and Rana pipiens in which the critical $\mathrm{P}_{2}$ was about 80 torr (Withers and Hillman, 1982b) and for aquatic salamanders in the critical $\mathrm{PO}_{2}$ was also 80 torr (Ultsch, 1973).

A $\mathrm{P}_{2}$ of 100 torr corresponds to about 3,000 meters in altitude; this exceeds the altitudinal distribution of amphibians (Hock, 1964). It therefore seems unlikely that $\dot{\mathrm{v}}_{\mathrm{O}_{2}}, \max$ is limited by altitudinally induced hypoxia. These results along with those of 


\section{TABLE I}

Hematological parameters for control and 100 torr chronic hypoxia acclimated Xenopus Zaevis. Values are mean \pm standard error. Asterisk indicates significant difference $(P<0.025)$. 


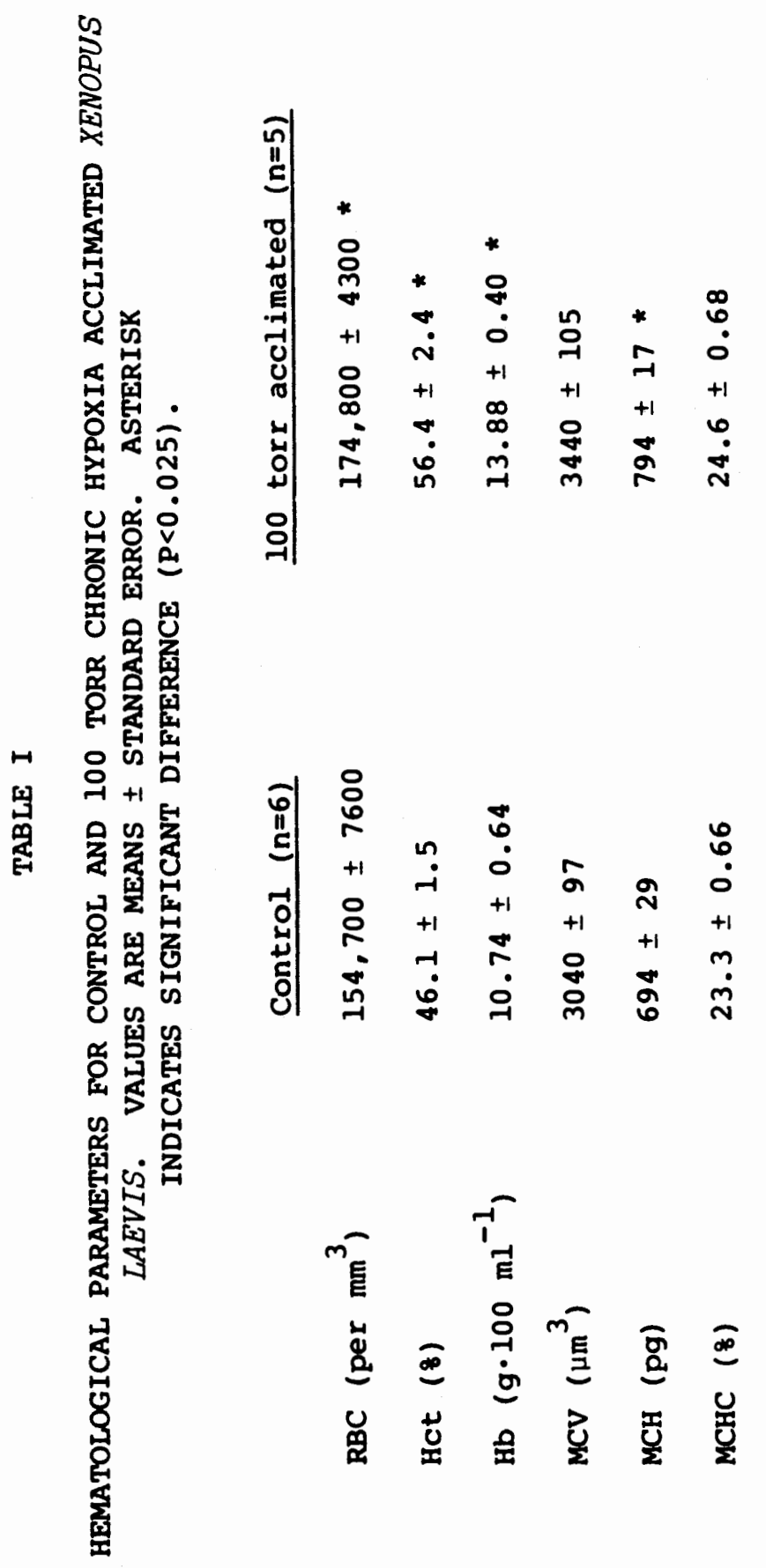


Withers (1980) and Hillman and Withers (1982), indicate that $\dot{\mathrm{V}}_{\mathrm{O}_{2}}$, $\max$ is not limited by diffusional exchange across the respiratory surface area at $\mathrm{P}_{2}$ normally encountered. Diffusional exchange is described by Fick's law of diffusion:

$$
\dot{v}_{\mathrm{O}_{2}}=D \cdot A \cdot \frac{\left(\mathrm{P}_{\mathrm{A}_{2}}-P_{\mathrm{a}_{2}}\right)}{d}
$$

where $D$ is the diffusion constant for $\mathrm{O}_{2}, \mathrm{~A}$ is the respiratory surface area, $\mathrm{P}_{\mathrm{A}_{2}}$ is alveolar $\mathrm{P}_{2}, \mathrm{~Pa}_{\mathrm{O}_{2}}$ is average pulmonary capillary $\mathrm{P}_{2}$ and $d$ is the diffusion distance. If $\dot{\mathrm{V}}_{2}, \max$ is limited by diffusional exchange across the respiratory surface area, then any decline in ambient $\mathrm{P}_{2}$ would decrease the oxygen gradient and $\dot{\mathrm{v}}_{\mathrm{O}_{2}}$, $\max$ would decline. There is, however, no decrease in $\dot{\mathrm{V}}_{\mathrm{O}_{2}}$, $\max$ with decreased $\mathrm{P}_{\mathrm{O}_{2}}$ until the critical $\mathrm{P}_{2}$ of 100 torr.

The $\dot{\mathrm{V}}_{\mathrm{O}_{2}}$, max declines linearly below the critical $\mathrm{P}_{\mathrm{O}_{2}}$ of 100 torr, indicating an $\mathrm{O}_{2}$ transport limitation at very low $\mathrm{P}_{2}$. The intercept of this regression line is $-0.084 \pm$ se -0.050 which is not different from zero (intercept $t$-test $=-1.68$, degrees of freedom $=$ 49). These data corroborate the findings of withers and Hillman (1982a) which indicate that there is a cardiovascular and not a respiratory limit to $\dot{\mathrm{V}}_{\mathrm{O}_{2}}$, $\max$ even at very low $\mathrm{P}_{\mathrm{O}_{2}}$ (see Figure 3 ). Hematology and Morphology

Packard and Stiverson (1976) observed no change in hemoglobin concentration in anurans along an altitudinal gradient from 1500 to 3000 meters. The results presented here indicate a slight increase 
Figure 3.

The $\dot{\mathrm{V}}_{\mathrm{O}_{2}}, \max \left(\mathrm{ml} \mathrm{O}_{2} \cdot \mathrm{g}^{-1} \mathrm{hr}^{-1}\right)$ versus ambient $\mathrm{P}_{\mathrm{O}_{2}} \cdot$ Graph shows values obtained in this paper (horizontal and vertical bars are two standard errors) and the predicted values (x) of Withers and Hillman (1982). 

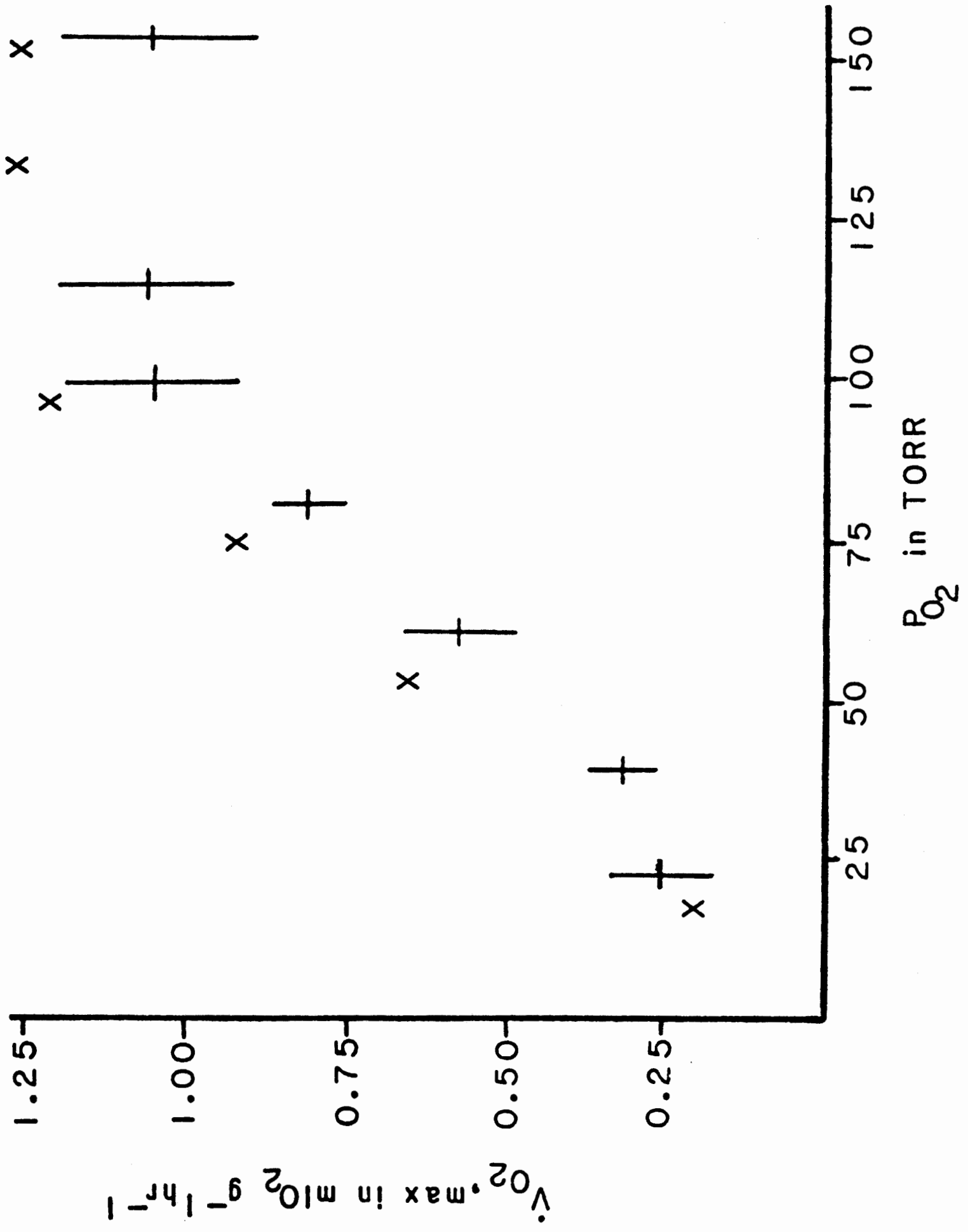
19

in hemoglobin concentration in animals acclimated to about $\mathrm{P}_{\mathrm{O}_{2}}=20$ torr, this increase mainly due to polycythemia. There was also a slight increase in $\mathrm{MCH}$, however, which might indicate that the new population of cells may have had a higher concentration of hemoglobin. The significant aspect of this moderate increase in hemoglobin concentration is that it was correlated with an increase in $\dot{\mathrm{V}}_{\mathrm{O}_{2}}$, $\max$ at the very lowest $\mathrm{P}_{2}\left(\mathrm{PO}_{2}=38\right.$ torr $)$. This is consistent with the model of Withers and tillman (1982a) which predicts that $\dot{\mathrm{V}}_{\mathrm{O}_{2}}$, $\max$ will increase with an increase in blood hemoglobin. Individual variability at higher $\mathrm{P}_{2}$ makes it impossible to detect small increases in $\dot{\mathrm{V}}_{2}, \max$ predicted by the model.

There was no significant change in lung and ventricle mass, indicating that there was no hypertrophy of these organs as a response to hypoxia. 
CHAPTER TWO

\section{INTRODUCTION}

Lactic acid accumulation has generally been considered to be an indication of the level of anaerobic metabolism (Bennett and Licht, 1974; Hutchison and Miller, 1979a; Hutchison and Miller 1979b; Preslar and Hutchison, 1978; Hillman and Withers, 1979; Carey, 1979b; Gleeson, 1980; Gatz and Piiper, 1979; Putnam, 1979b) and has been measured during activity in virtually every class of vertebrates (Wardle, 1978; Gleeson, 1980; Hutchison and Miller, 1979a; Taigen et al., 1982; Bartholomew et al., 1976; Dean and Goodnight, 1964; Gatten, 1975; Hermansen and Vaage, 1977; Issekutz et al.. 1976).

A major effect of the accumulation of lactic acid is the concomitant decrease in tissue and plasma pH. This disruption of the acid-base balance of the tissue can eventually incapacitate the muscle and has been implicated as the cause of fatigue (Hermansen and Osnes, 1972; Mainwood and Worsley-Brown, 1975). Putnam (1979b), however, has shown that behavioral recovery in Xenopus laevis and Rana pipiens can be accomplished in both the intact organism and isolated gastrocnemius muscle without lactate disappearance or recovery from $\mathrm{pH}$ imbalance. Decreased pH can, however, have a marked effect on many systems including oxygen delivery due to the Bohr effect, enzyme function and blood bicarbonate buffer system.

The fate of lactic acid is unclear, despite the plethora of data 
available concerning its production, levels during activity and adverse effects. Original studies on the fate of lactate on isolated frog muscle indicated that about 808 of the lactate was reconverted to glycogen and 208 oxidized aerobically (Hill, 1922). Later results using intact rats fed ${ }^{11} \mathrm{C}$ - labelled lactate revealed that from 10-208 of the lactate was oxidized and 21-328 of the lactate was converted to liver glycogen (Conant et al.. 1941; Vennesland et al.. 1942). depending on which carbon atoms were labelled.

The Cori cycle is the most widely accepted model of lactate metabolism. According to the Cori cycle, lactate diffuses from the muscle to the blood and is transported to the liver where it is reconverted to glucose and stored as glycogen (Guyton, 1981). This resynthesis is energetically expensive, requiring 6 ATP to convert 2 lactate molecules to one glucose molecule, whereas the original anaerobic yield of glucose catabolism to lactate was only 2 ATP (Lehninger, 1975). An advantage of glucose resynthesis in mammals is that it restores acid-base balance very rapidly. In lower vertebrates, however, very high levels of lactate are accumulated and remain for a considerable time, up to 36 hours (Withers and Hillman, 1981). Consequently acid-base imbalance may also be prolonged for up to 36 hours.

Recent studies concerning the fate of lactic acid after activity, essentially all on mammals (Drury and Wick, 1956; Brooks et al., 1973; Issekutz et al., 1976; Hermansen and Vaage, 1977; McLane and Holloszy, 1979; Brooks and Gaesser, 1980) have led to the conclusion that the Cori cycle cannot account for either lactate disappearance or glycogen 
synthesis and suggest that lactate is either mainly converted to glycogen in the muscle itself (Hermansen and Vaage, 1977; McLane and Holloszy, 1979) or mainly oxidized to $\mathrm{CO}_{2}$ (Brooks and Gaesser, 1980; Drury and wick, 1956). Clearly the controversy over the metabolic fate of lactate in mammals is not settled, and much more research is needed.

Anaerobic metabolism is of more routine significance in the lower vertebrates, yet there is very little data regarding how these animals metabolize lactate. What little has been published is mainly on isolated frog muscle (Bendall and Taylor, 1970) or fish (Hochachka, 1961). Cushman et al. (1976), in one of the few in vivo studies, found that tiger salamanders do not excrete lactate into the aquatic environment but gave no indication as to its fate.

The purpose of this investigation is to determine, using ${ }^{14} \mathrm{C}-$ labelled lactic acid, the fate of endogenous lactic acid accumulated during activity in anurans. The main concerns were; are the labelled carbon atoms incorporated into specific tissues; how much of the lactate is oxidized aerobically; and how much, if any, of the lactate is excreted directly to ameliorate the acid-base disturbance. Three species of anurans were studied, each having a different mode of energy production. Rana pipiens is a primarily anaerobic frog; Bufo cmericanus is a primarily aerobic toad; and Xenopus Zaevis is intermediate in metabolic strategies, with a high $\dot{\mathrm{V}}_{2}$, max during and high lactate concentrations following exercise. Whole body lactate concentrations were measured for Xenopus laevis following recovery periods of various durations after exhaustive exercise in order to 
establish a time course for lactate removal. Oxygen consumption was also measured over the entire recovery period.

MATERIALS AND METHODS

Lactate Removal Rate and Oxygen Consumption During Recovery

Xenopus Zaevis were manually stimulated to be active by the method of Seymour (1973) and Hillman (1976). The animals were placed in a closed metabolic chamber (volume $=450 \mathrm{ml}$ ) and the chamber manually rotated to keep the animal constantly righting itself, after it had been flipped on its back. The activity bout was 10 minutes. An air sample was withdrawn into a $50 \mathrm{ml}$ syringe following activity. The sample was passed through Drierite and Ascarite to absorb water vapor and carbon dioxide respectively, and oxygen content measured with a Beckman OM-14 polarographic oxygen analyser.

The animals were immediately placed in $50 \mathrm{ml}$ syringes and held in the dark for the recovery period. The air in the syringes was analysed for oxygen content after various time intervals in the manner described above, and the air in the syringes replenished. Values for oxygen consumption $\left(\dot{\mathrm{V}}_{2}\right)$ are expressed as $\mathrm{ml} \mathrm{O}_{2} \mathrm{~g}^{-1} \mathrm{hr}^{-1}$.

Animals were sacrificed at various time intervals and whole body lactate concentrations measured. The method for determining whole body lactate was similar to that of Putnam (1978) and Bennett and Licht (1974). Animals were homogenized in 88 perchloric acid (volume $=10$ times body mass), centrifuged at $3000 \mathrm{~g}$ for 10 minutes and the supernatant filtered. The supernatant was then analysed for lactate with a commercial lactic acid kit (Sigma Lactic Acid Kit, No. 826-UV). 
This assay is based on the enzymatic conversion of lactate to pyruvate which yields an increase in absorbance at $340 \mathrm{~nm}$ due to the reduction of $\mathrm{NAD}^{+}$. Optical density at $340 \mathrm{~nm}$ was determined with a Perkin-Elmer model 124D spectrophotometer.

Fate of $c^{14}$-Lactate

The fate of lactic acid after exercise was examined for Xenopus Zaevis, Rana pipiens and Bufo americanus using exogenous administration of $\mathrm{C}^{14}$-lactate.

The animals were injected, following exercise, in the dorsal lymph sac with $2 \mu \mathrm{Ci}$ of universally labelled $c^{14}$-lactate $\left(\mathrm{C}^{14} \mathrm{H}_{3} \mathrm{C}^{14} \mathrm{HOH}-\mathrm{C}^{14} \mathrm{OOH}\right)$ obtained from New England Nuclear (specific activity, $165.2 \mathrm{mCi} / \mathrm{mmol})$. The animals were then placed in $50 \mathrm{ml}$ of water for 10 minutes. This water was then sampled $(50 \mu 1)$ and analysed for $\mathrm{C}^{14}$-lactate to determine the extent of possible leakage of $c^{14}$-lactate from the injection site. The animals were then placed in a chamber with $100 \mathrm{ml}$ (for $X$. Zaevis and $R$. pipiens) or $50 \mathrm{ml}$ (for B. comericanus) of water and allowed to recover undisturbed. Recovery times were chosen in accordance with the observed values for whole body lactate removal ( 8 hours for $X$. Zaevis, see results) and literature values for $R$. pipiens (8 hours; Hutchison and Turney, 1975) and $B$. americanus ( 3 hours; Hutchison and Miller, 1979a).

Ambient air was pumped through the chamber during the recovery period, and excurrent air was bubbled through two $\mathrm{CO}_{2}$ traps, each consisting of $50 \mathrm{ml}$ of saturated $\mathrm{KOH}$. Sampling of the $\mathrm{KOH}$ at regular time intervals throughout recovery and analysis for B-emission yielded 
a quantitative measure of total $\mathrm{c}^{14} \mathrm{O}_{2}$ expired by the animal.

At the end of the recovery period, the animals were weighed,

then doubly-pithed and a blood sample obtained from the ventricle in a heparinized capillary tube. The blood sample was centrifuged for 5 minutes to obtain a $20 \mu 1$ plasma sample which was placed directly into $10 \mathrm{ml}$ of Aquasol-2 scintillation cocktail (New England Nuclear). The animal was then dissected and representative tissues and organs weighed to the nearest $0.1 \mathrm{mg}$. Samples included muscle (gastrocnemius or posterior thigh muscles), ventricle, lung, liver, skin and gastrointestinal tract. The samples were digested with $0.2 \mathrm{ml}$ concentrated perchloric acid and $0.4 \mathrm{ml} 808$ hydrogen peroxide at $60^{\circ} \mathrm{C}$ in an agitating water bath for 60 minutes. The resulting digest was cooled and $10 \mathrm{ml}$ Aquasol-2 scintillation cocktail added. Samples were analysed for $\beta$-emission using a microprocessor controlled Beckman LS-9000 liquid scintillation counter. The machine was standardized with Beckman $\mathrm{C}^{14}$ standards and the counting time was 60 minutes or one 2 Si error. Results were disintegrations per minute (DPM), converted from the counts per minute (CPM). Details of the counting program, counting efficiency and DPM calculation are given in Appendix A.

\section{RESULTS}

\section{Oxygen Consumption Rates and Lactate Concentrations During Recovery}

The results obtained for the maximal rate of oxygen consumption $\left(\dot{\mathrm{V}}_{\mathrm{O}_{2}}, \mathrm{max}\right)$ and the rate of oxygen consumption during recovery $\left(\dot{\mathrm{V}}_{\mathrm{O}_{2}}, \mathrm{rec}\right)$ are given in Figure 4. The $\dot{\mathrm{V}}_{\mathrm{O}_{2}}, \max$ was $1.09( \pm$ se 0.14$) \mathrm{ml} \mathrm{O}_{2} \cdot \mathrm{g}^{-1} \mathrm{hr}^{-1}$ $(n=16)$. The $\dot{\mathrm{V}}_{\mathrm{O}_{2}}$ declined rapidly after activity and was at a standard 
$\dot{\mathrm{v}}_{2}$ of $0.1 \mathrm{ml} \mathrm{O}{ }_{2} \cdot \mathrm{g}^{-1} \mathrm{hr}^{-1}$ at 120 minutes after activity and remained at this level throughout the six hour recovery period.

The results for whole body lactate concentrations are given in Figure 5. The regression line for lactate removal was [lactate] = $-0.26( \pm$ se -0.05$) \times$ time $+113.15( \pm$ se 7.49$) ;\left(r^{2}=0.56 ; n=23\right)$. Maximal lactate levels were 128.36 ( \pm se $13.50 ; n=7$ ) immediately after activity $\left(t_{\text {rec }}=0\right.$ and $\left.15 \mathrm{~min}\right)$. Resting lactate levels of $10 \mathrm{mg}$. $100 \mathrm{ml}^{-1}$ (Putnam, 1979b) were not attained by the end of the six hour recovery period, but were extrapolated from the regression line to be attained at $t_{\text {rec }}=8$ hours.

\section{Fate of Lactic Acid}

Results for the fate of lactic acid were calculated as the percentage of the injected ${ }^{14} \mathrm{C}$-labelled lactic acid DPM minus the DPM counted in the 10 minute post-activity recovery water (to account for leakage from the injection site). Results are given as percent DPM $(8 D P M)$ and percent $D P M$ per $g r a m\left(\& D P M \cdot g^{-1}\right)$ and are summarized in Table II.

The percentage of label recovered as $\mathrm{CO}_{2}$ is presented in Figure 6 for $R$. pipiens and in Figure 7 for $B$. americanus. $R$. pipiens oxidized approximately 48 of the injected label and $B$. comericanus oxidized approximately 28 of the injected label.

The liver, lung, ventricle and blood contained significantly more lactate, both in absolute amounts (\&DPM) and mass specific amounts $\left(8 D P M \cdot g^{-1}\right)$, in $B$, conericanus than in $R$. pipiens, whereas the muscle of $R$, pipiens contains more $c^{14}$ activity than the muscle of 
$B$. comericanus, in both $8 D P M$ and $8 D P M \cdot g^{-1}$.

\section{DISCUSSION}

Oxygen Consumption Rates and Lactate Disappearance During Recovery

The $\dot{\mathrm{V}}_{2}$ of Xenopus Zaevis dropped rapidly during recovery and reached standard levels in all animals within two hours of the end of activity. The rate of lactate disappearance does not coincide with the $\dot{\mathrm{V}}_{\mathrm{O}_{2}}$. Resting levels of lactate are not achieved after six hours of recovery. By extrapolation of the regression line, time of recovery to resting rates of lactate is eight hours.

Hutchison and Miller (1979b) report return to resting lactate levels in Xenopus Zaevis at nine hours. Differences in the stimulation technique (electrical vs. manual stimulation) may, in part, account for the difference. Hutchison and Miller (1979b) also obtained higher whole body lactate concentrations of $222 \mathrm{mg} \cdot 100 \mathrm{ml}^{-1}$. This is also possibly due to electrical stimulation (Putnam, 1979b; Hillman et al.. 1979). Putnam (1979b) obtained higher whole body lactate concentrations $\left(213 \mathrm{mg}^{\cdot} 100 \mathrm{ml}^{-1}\right)$ using manual stimulation. The technique used was forced swimming, a regimen which possibly involves more muscle groups and possibly led to fatigue more rapidly.

\section{Fate of Lactic Acid}

The liver, lung, ventricle and blood contained significantly more lactate per gram in Bufo americanus than Rana pipiens, while muscle contained more lactate per gram in $R_{0}$ pipiens than $B$. comericanus. Rana pipiens depends primarily on anaerobic metabolism 


\section{TABLE II}

The fate of lactic acid in some anuran amphibians. Values are means \pm standard error for Rana pipiens $(n=4)$ and Bufo americanus $(n=4)$. Values for Xenopus Zaevis for 4 hour $(n=2)$ and 8 hour $(n=2)$ recovery are means. 


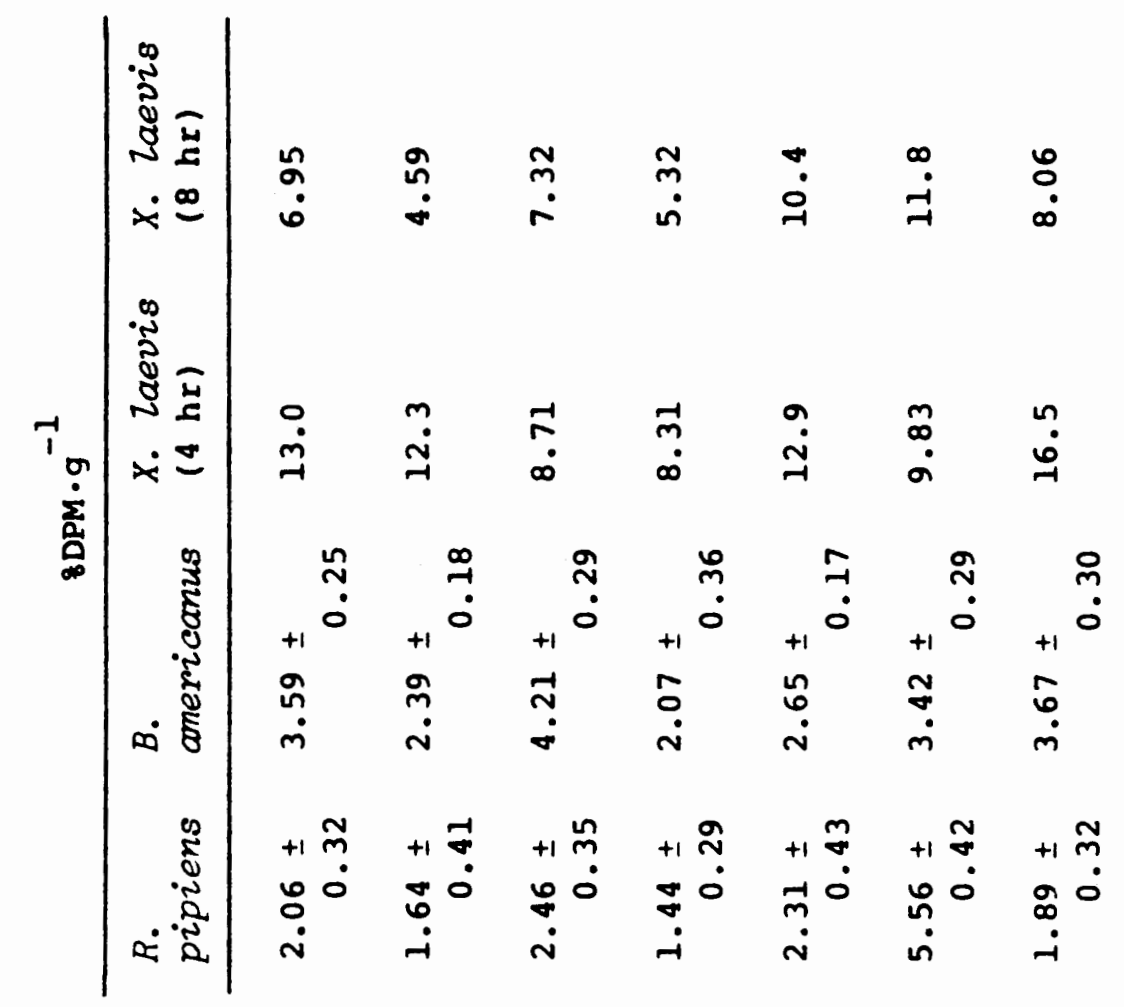

点

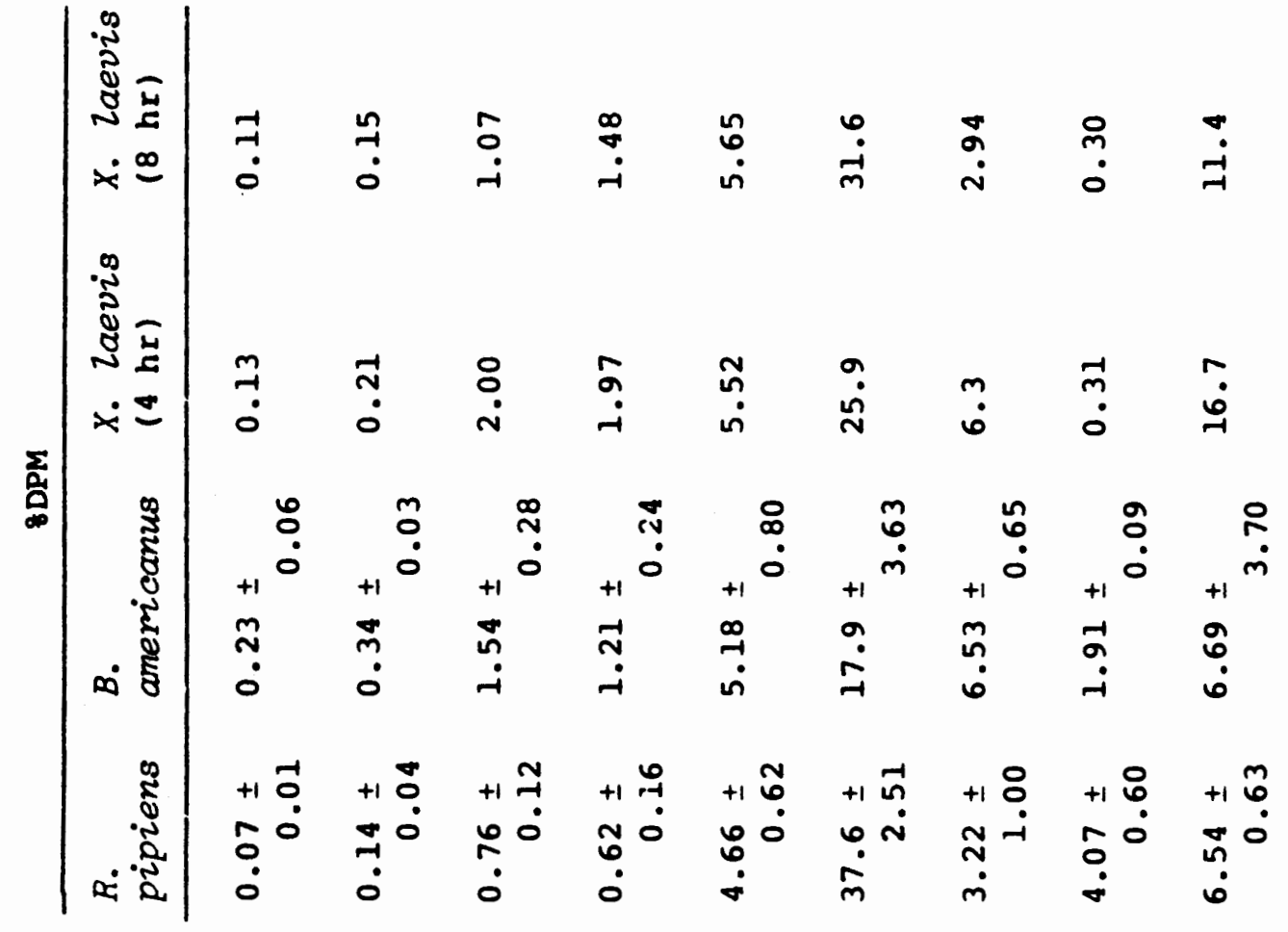

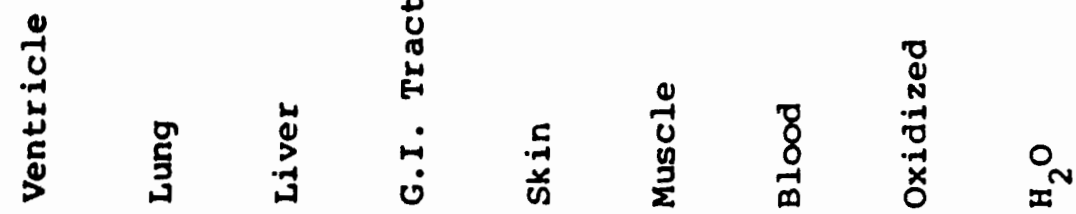

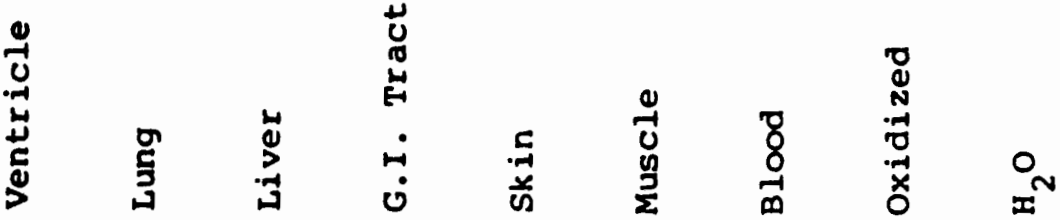




\section{Figure 4.}

The rate of oxygen consumption $\left(\mathrm{V}_{2}\right)$ in $\mathrm{ml} \mathrm{O}_{2} \cdot \mathrm{g}^{-1} \mathrm{hr} \mathrm{r}^{-1}$ during recovery from exhaustive exercise versus time of recovery. 


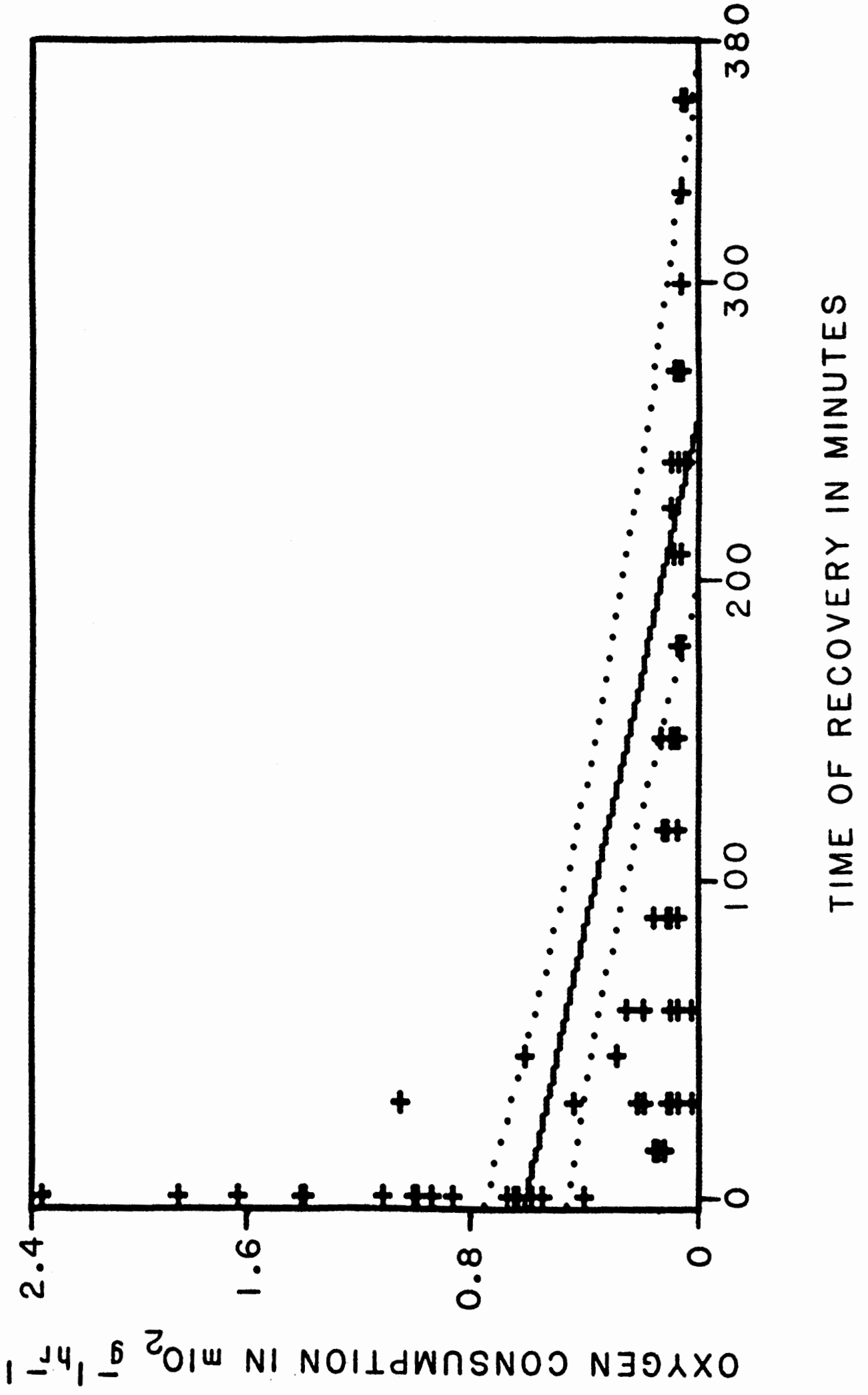




\section{Figure 5.}

Whole body lactate concentrations $\left(\mathrm{mg} \cdot 100 \mathrm{ml}^{-1}\right.$ ) during recovery from exhaustive exercise versus time of recovery (in minutes). 


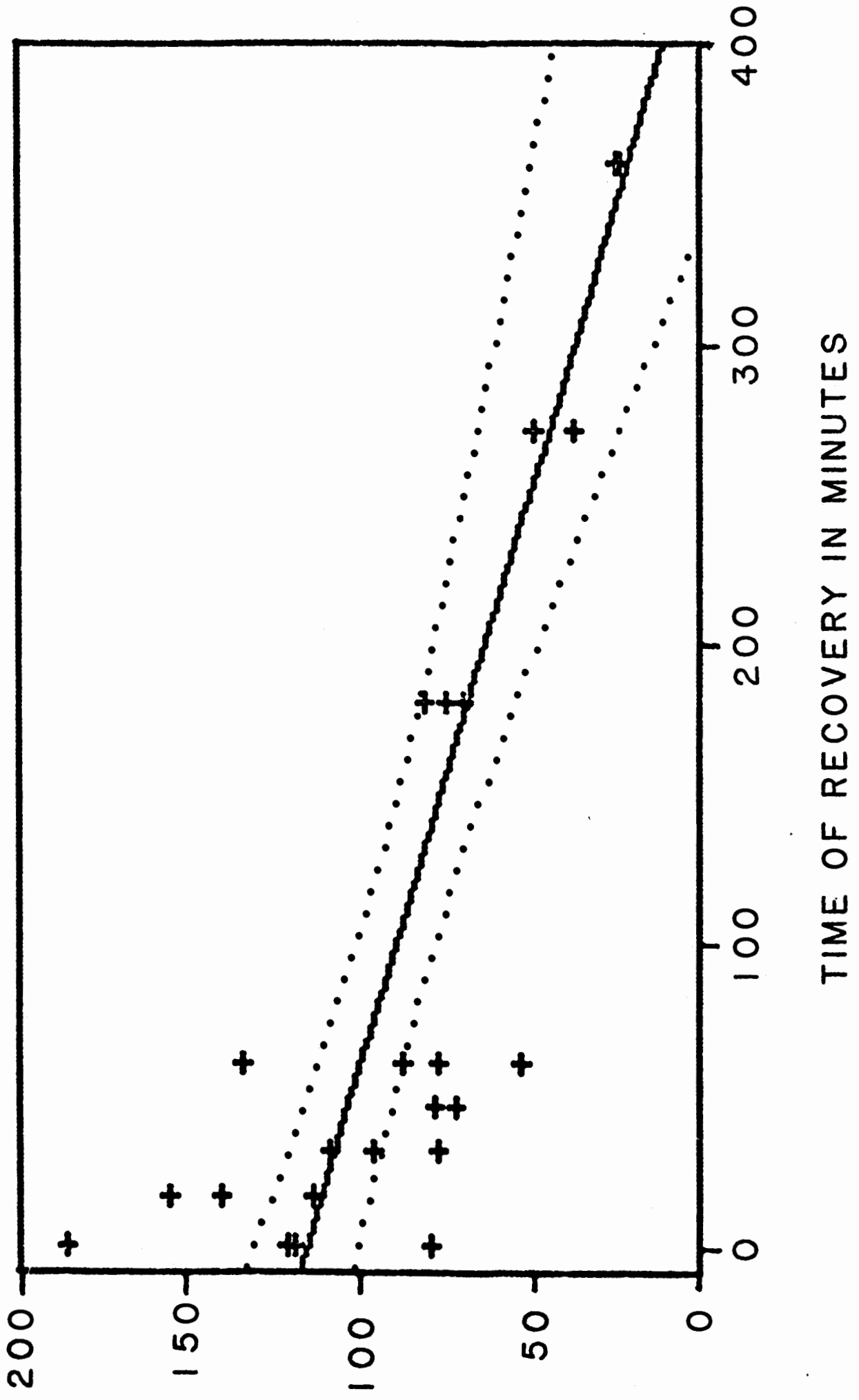

$\% 6 ய N I N O I \perp \forall \forall \perp N \exists O N O O \exists \perp \forall \perp O \forall 7$ 
Figure 6 .

The percentage of $\mathrm{C}^{14}$ label injected ( $\left.8 D \mathrm{DPM}\right)$ recovered as expired $\mathrm{C}^{14} \mathrm{O}_{2}$ versus time of recovery (hours) for Rana pipiens. 


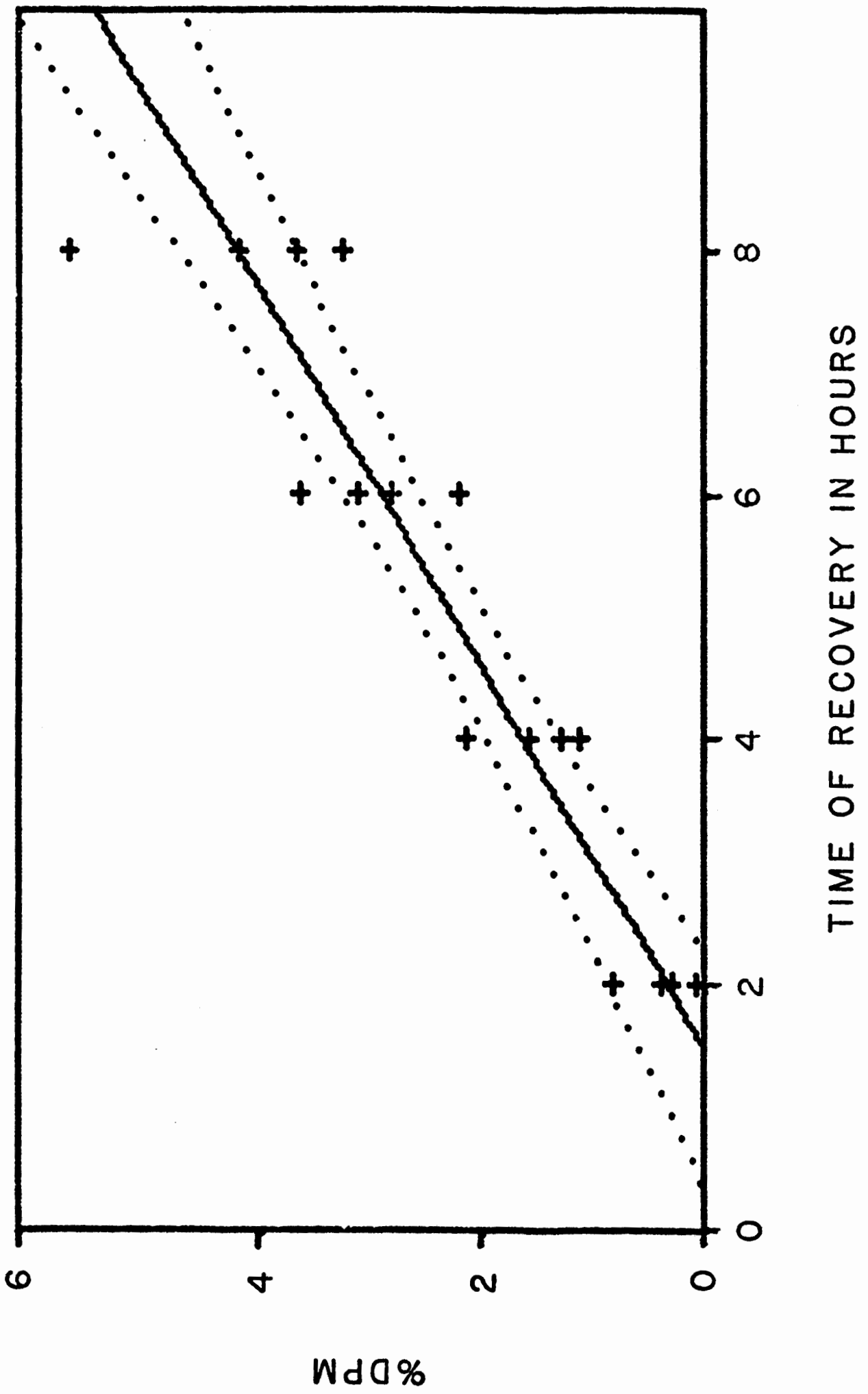


Figure 7.

The percentage of $\mathrm{C}^{14}$ label injected (8DPM) recovered as expired $\mathrm{c}^{14} \mathrm{O}_{2}$ versus time of recovery (hours) for Bufo americanus. 


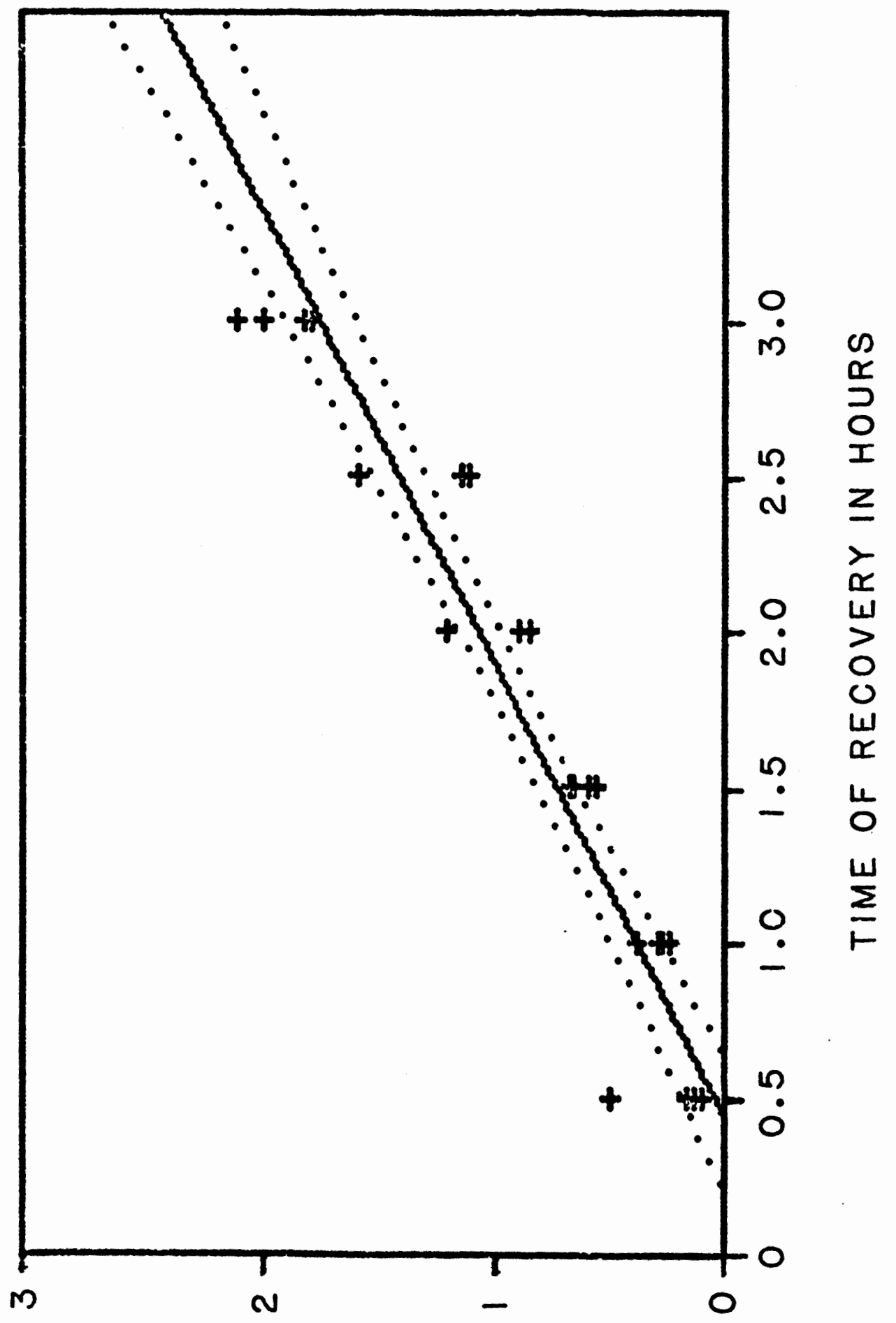

WdO\% 
during activity. It is necessary, therefore, that a readily available supply of glucose is available in the muscle tissue for burst activity. Although the experiments presented here do not include biochemical assays to determine the nature of the molecules that the labelled carbon is incorporated into, it is likely that a significant portion is in glycogen. Previous studies of mammalian systems have indicated that a large percentage of endogenous lactate is converted to glycogen (Hermansen and Vaage, 1977; McLane and Holloszy, 1979). Bendall and Taylor (1970), working with isolated frog sartorius muscle, concluded that almost 80 of the endogenous lactate was converted to glycogen, either within the muscle or by another tissue such as the liver in the Cori cycle. The animal, therefore, has adequate muscle glucose for subsequent burst anaerobic metabolism. Storing the carbons from lactic acid in other compounds such as fatty acids or proteins would be of little value for a principally anaerobic species such as $R$. pipiens, because fat and protein are not suitable substrates for anaerobiosis. When large fat bodies were found during dissection, they were dissolved in $10 \mathrm{ml}$ of scintillation cocktail and analysed for $\mathrm{c}^{14}$. Very little of the $\mathrm{c}^{14}$ (approximately $0.8 \mathrm{8DPM} \cdot \mathrm{g}^{-1}$ ) was incorporated into fat.

Less $\mathrm{C}^{14}$ activity was found in the muscle of $B$. americonus and more activity was found in the lung, liver, ventricle and blood. This species has a primarily aerobic metabolic strategy, therefore the demand for readily available muscle glucose reserves is less. Apparently more of the lactate is metabolized by tissues other than the muscle in $B$. comericonus. 
Aerobic oxidation accounted for approximately 48 of the lactate in $R$. pipiens and about 28 in $B$. americanus. These are much lower than reported values for the fate of lactate, which range from 108 expired in rats (Vennesland et al., 1942) to 80-908 expired in rabbits (Drury and Wick, 1956). Bendall and Taylor (1970) found that isolated frog sartorius muscles oxidized 208 or less of the lactate that accumulated during activity. Oxidation of lactate directly would, a priori, appear to be a likely fate of lactate. The lactate removal rate is slow, and the $\dot{\mathrm{V}}_{2}$ is low in anurans compared to mammals, after anaerobic activity. Resynthesis of one molecule of glucose from two molecules of lactate is energetically expensive, requiring 6 ATP, therefore direct oxidation appears energetically favorable.

Lactate does not appear to be oxidized by these anurans, however, and it appears that lactate is not preferentially metabolized. The animals were injected with 0.012 umoles of labelled lactate. In a 20 g frog which accumulated $128 \mathrm{mg} \cdot 110 \mathrm{ml}^{-1}$ of lactate, the ratio of unlabelled to labelled lactate is approximately $2.4 \times 10^{4}: 1$. Over the recovery period, the frog consumed about $16 \mathrm{ml}$ of oxygen $10.2 \mathrm{ml}$ $\mathrm{O}_{2} \cdot \mathrm{g}^{-1} \mathrm{hr} \mathrm{r}^{-1}$ for 8 hours). Assuming an $\mathrm{RQ}$ of $1,16 \mathrm{ml}$ or 710 umoles of $\mathrm{CO}_{2}$ are produced. The mean values for umoles of $\mathrm{C}^{14} \mathrm{O}_{2}$ produced for R. pipiens was $4.4 \times 10^{-4}$. The ratio of unlabelled to labelled $\mathrm{CO}_{2}$ was, therefore, $1.6 \times 10^{6}$ : 1. This value is 67 times greater than the unlabelled to labelled lactate ratio. It, therefore, seems unlikely that the exogenous, labelled lactate is simply equilibrating with the general body carbon pool. Lactate appears to be preferentially removed by some pathway other than aerobic metabolism; 
the endogenous lactic acid is presumably removed in the same manner.

Sample sizes for the two groups of $X$. Zaevis are, of course, too

small to be of significance; nevertheless, some trends are suggested

which are of interest. After 4 hours of recovery, over one-half of the recovered label is found in the ventricle, lung, liver and blood. All of these tissues decline in $8 D P M \cdot g^{-1}$ after 8 hours recovery, and there is a slight increase in the muscle $8 D P M \cdot g^{-1}$. In $X$. Zaevis the amount of $\mathrm{c}^{14}$ recovered as $\mathrm{CO}_{2}$ is negligible (less than 0.5 8DM); this is consistent with other $X$. Laevis analysed in preliminary experiments not reported here. It is, therefore, apparent that $X$. Zaevis oxidizes almost no lactate during recovery.

There has been very little data concerning the fate of lactate, especially in amphibians. It has generally been assumed on energetic grounds, that the majority of the lactate accumulated after activity was oxidized (Preslar and Hutchison, 1979; Withers and Hillman, 1981). The data presented here indicate that oxidation contributes very little to the removal of lactate.

The carcass remaining after the dissection was dissolved in saturated $\mathrm{KOH}$ in order to determine the total recovery of the $c^{14}$ activity. Total recovery was determined as the sum of the tissue samples \&DPM, the oxidized $\mathrm{C}^{14} \mathrm{O}_{2}$ \&DPM, the recovery waters \&DPM, the carcass $8 D P M$ and an extrapolated estimation of the fluid lost in dissection (based on the difference in initial body mass and the sum of the tissue masses after dissection). Total recovery of the $c^{14}$ activity was $80.1 \pm 5.88$ for $R$. pipiens and $90.3 \pm 13.08$ for $B$. comericanus. Mahin and Lofberg (1966) report that the digestion 
technique used here may be accompanied by a 108 loss of $c^{14}$ activity due to the production of $\mathrm{C}^{14} \mathrm{O}_{2}$. 


\section{REFERENCES}

Armentrout, D. and F.I. Rose (1971) Some physiological responses to anoxia in the Great Plains Toad, Bufo cognatus. Comp. Biochem. Physiol. 39A: 447-455.

Bartholomew, G.A. and A.F. Bennett and W. Dawson (1976) Swimming, diving and lactate production in the marine iguana, Amblyrhyncins cristatus. Copiea. 709-720.

Bendal1, S.R. and A.A. Taylor (1970) The Meyerhof Quotient and the synthesis of glycogen from lactate in frog and rabbit muscle. Biochem. J. 118: 887-893.

Bennett, A.F. (1978) Activity metabolism of the lower vertebrates. Ann. Rev. Physiol. 400: 447-469.

Bennett, A.F. and P. Licht (1973) Relative contributions of anaerobic and aerobic energy production during activity in amphibia. J. Comp. Physiol. 87: 351-360.

Bennett, A.F. and P. Licht (1974) Anaerobic metabolism during activity in amphibians. Comp. Biochem. Physiol. 48A: 319-327.

Boutilier, R.G. and D.P. Towes (1977) The effect of progressive hypoxia on respiration in the toad, Bufo marinus. J. Exp. Biol. 68: 99-107.

Brooks, G.A., K.E. Brauner, and R.G. Lassens (1973) Glycogen synthesis and the metabolism of lactic acid after exercise. Am. J. Physiol. 224: 1162-1166.

Brooks, G.A., and G.A. Gaesser (1980) End points of lactic and glucose metabolism after exhausting exercise. J.App. Physiol. 1057-1069.

Carey, C. (1979a) Effect of constant and fluctuating temperatures on resting and active oxygen consumption of toad, Bufo boreas. Oecologia. 39: 201-212.

Carey, C. (1979b) Aerobic and anaerobic energy expenditure during rest and activity in montane Bufo $b$. boreas and Rana pipiens. Oecologia. 39: 213-228. 
Conant, J.B., R.D. Cramer, A.B. Hastings, F.W. Klemperer, A.K. Solomon, and B. Vennesland (1941) Metabolism of lactic acid containing radioactive carboxyl carbon. J. Biol. Chem. 137: 557-566.

Cushman, J.R., G.C. Packard, and T.V. Boardman (1976) Concentrations of lactic acid in neotenic and transformed tiger salamanders (Ambystoma tigrinum) before and after activity. J. Comp. Physiol. 112: 273-281.

Dean, J.M. and C.V. Goodnight (1964) A comparative study of carbohydrate metabolism in $f i s h$ as affected by temperature and exercise. Physiol. Zool. 37: 280-299.

Drury, D.R. and A.N. Wick (1956) Metabolism of lactic acid in the intact rabbit. Am. J. Physiol. 184: 305-308.

Gatten, R.E., Jr. (1975) Effects of activity on blood oxygen saturation, lactate, and $\mathrm{pH}$ in the turtles Pseudomys scripta and Terrapene ormata. Physiol. zool. 48: 24-35.

Gatz, R.N. and J. Piiper (1979) Anaerobic energy metabolism during severe hypoxia in the lungless salamander, Desmognathus fuscus (Plethodontidae). Respir. Physiol. 38: 377-384.

Gleeson, Todd T. (1980) Metabolic recovery from exhaustive activity by a large lizard. J. Appl. Physiol. 48: 689-694.

Guyton, A.C. (1981) Textbook of Medical Physiology. W.B. Saunders Co. Philadelphia.

Hermansen, L. and J.B. Osnes (1972) Blood and muscle pH after maximal exercise in man. J. Appl. Physiol. 32: 304-322.

Hermansen, L. and O. Vaage (1977) Lactate disappearance and glycogen synthesis in human muscle after maximal exercise. Am. J. Physiol. 233(5): E422-E429.

Hill, A.V. (1922) The mechanism of muscle contraction. Physiol. Rev. 2: 310 .

Hillman, S.S. (1976) Cardiovascular correlates of maximal oxygen consumption rates in anuran amphibians. J. Comp. Physiol. 109: 199-207.

Hillman, S.S., V.H. Shoemaker, R. Putnam, and P.C. Withers (1979) Reassessment of aerobic metabolism in amphibians during activity. J. Comp. Physiol. 129: 309-313. 
Hillman, S.S. and P.C. Withers (1979) An analysis or respiratory surface area as a limit for activity metabolism in anurans. Can. J. 2001. 57: 2100-2105.

Hochachka, P.W. (1961) The effect of physical training on oxygen debt and glycogen reserves in trout. Can. J. Zool. 39: 767-776.

Hochachka, P.W. (1980) Living Without Oxygen. Harvard University Press, Cambridge, MA.

Hock, R.J. (1964) Animals at high altitude: reptiles and amphibians. p. 841-842. In D.B. Dill (Ed). Handbook of Physiology, Section 4, Adaptations to the Environment. Am. Physiol. Soc., Washington D.C.

Hutchison, V.H. and K. Miller (1979a) Anaerobic capacity of amphibians. Comp. Biochem. Physiol. 63A: 213-216.

Hutchison, V.H. and K. Miller (1979b) Aerobic and anaerobic contributions to sustained activity in Xenopus Zaevis. Respir. Physiol. 38: 98-103.

Hutchison, V.H. and I.D. Turney (1975) Glucose and lactate concentrations during activity in the leopard frog Rana pipiens. J. Comp. Physiol. 99: 287-295.

Hutchison, V.H., L.D. Turney, and R.K. Gratz (1977) Aerobic and anaerobic metabolism during activity in the salamander Ambystoma tigrinum. Physiol. zool. 50: 189-202.

Issekutz, B., Jr., W.A.S. Shaw, and A.C. Issekutz (1976) Lactate metabolism in resting and exercising dogs. J. Appl. Physiol. $40(3)$ : $312-319$.

Jones, D.R. and T. Mustafa (1973) The lactacid debt in frogs after one hours aphoea in air. J. Comp. Physiol. 85: 15-24.

Lehninger, A.L. (1975) Biochemistry. 2nd Ed. Worth Publishers Inc. New York.

Mahin, D.T. and D.T. Lofberg (1966) A simplified method of sample preparation for determination of tritium, carbon-14 or sulfer-35 in blood or tissue by liquid scintillation counting. Anal. Biochem. 16: 500-509.

Mainwood, G.W. and P. Worsley-Brown (1975) The effects of extracellular pH and buffer concentration on the efflux of

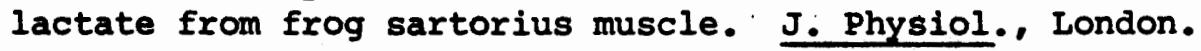
250: 1-22. 
McLane, Jerry A. and John O. Holloszy (1979) Glycogen synthesis from lactate in the three types of skeletal muscle. 'J. Biol. Chemistry. 254(14): 6548-6553.

Packard, G.C. and R.K. Stiverson (1976) Blood hemoglobin concentration in chorus frogs (Pseudocris triseriata): Relationships to body size and altitude. Am. Midl. Nat. 96: 482-487.

Preslar, A.J. III and V.H. Hutchison (1978) Energetics for activity in the salamander Amphiuma means. J. Comp. Physiol. 128: 139-146.

Putnam, R.W. (1979a) The basis for differences in lactic acid content after activity in different species of anuran amphibians. Physiol. Zool. 52: 509-519.

Putnam, R.W. (1979b) The role of lactic acid accumulation in muscle fatigue in two species of anurans, Xenopus Zaevis and Rana pipiens. J. Exp. Biol. 82: 35-51.

Putnam, R.W. and A.F. Bennett (1981) Thermal dependence of behavioral performance of anuran amphibians. Anim. Behav. 29: 502-509.

Seymour, R.S. (1973) Physiological correlates of forced activity and burrowing in the spadefoot toad, Scaphiopus hommondi. Copeia. 193: 103-115.

Taigen, T.I., S.B. Emerson, and F.H. Pough (1982) Ecological correlates of anuran exercise physiology. Oecologia. 52(1): 49-56.

Ultsch, G.R. (1973) A theoretical and experimental investigation of the relationships between metabolic rate, body size, and oxygen exchange capacity. Respir. Physiol. 18: 143-160.

Vennesland, B., A.K. Solomon, J.M. Buchanan, R.D. Cramer, and A.B. Hastings (1942) Metabolism of lactic acid containing radioactive carbon in the $\alpha$ or $B$ position. J. Biol. Chem. 142: $371-377$.

Wardle, C.S. (1978) Non-release of lactic acid from anaerobic swimming muscles of plaice Pleuronectes platessa L.: a stress reaction. J. Exp. Biol. 77: 101-155.

Withers, P.C. (1980) Oxygen consumption of plethodontid salamanders during rest, activity and recovery. Copiea $1980(4)$ : 781-787. 
Withers, P.C. and S.S. Hillman (1981) Oxygen consumption of Amphizma means during forced activity and recovery. Comp. Biochem. Physiol. 69A: 141-144.

Withers, P.C. and S.S. Hillman (1982a) A computer simulation of maximal oxygen transport rate in anuran amphibians. (M.S.).

Withers, P.C. and S.S. Hillman (1982b) The effect of hypoxia on pulmonary function and maximal rates of oxygen consumption in two anuran amphibians. (M.S.). 


\section{APPENDIX A}

A copy of the counting program is on the following page. Counting efficiencies were calculated internally by the following formula:

$$
\& \text { efficiency }=\frac{C P M(\text { observed })-\text { background }}{\text { DPM (in sample) }} \times 100
$$

Counting efficiency was based on calibration with Beckman $c^{14}$ standards and was determined as:

$$
\text { counting efficiency }=A+B x+C x^{2}+D x^{3}
$$

where $x=H$ number and $A, B, C, D=$ Quench mode coefficients. Disintegrations per minute (DPM) is then calculated by:

$$
D P M=\frac{C P M \text { (sample) - background }}{\text { counting efficiency }}
$$

The error factor $\sigma(8)$ error is the real error calculated and based on actual counting data:

$$
\pm 2 \sigma(z)= \pm \frac{200}{\sqrt{N}}
$$

Where $\mathbf{N}$ is the total number of counts obtained at the time of calculation. 


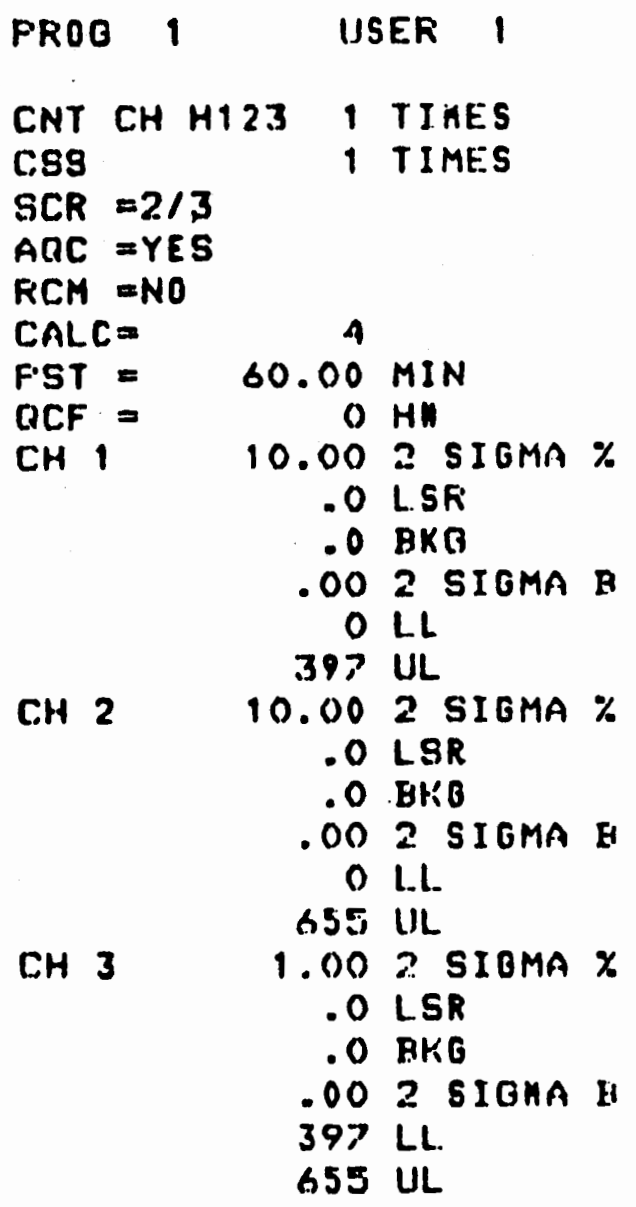

SINGLE L.ABEL DFM-UERS:08/01/76

1. STAMDAFIIS III: BUCKMAN C:I4

2. UNK III TUAD LACTATE UHKNOUN NOFIMALIZATION FACTOR: 1.00900000

3. DATA CHANNEL: 3

4. QUUENCH KONE: H BKBRII CONGTANT DUENCH'? $Y$

5. HAL.F L.JFE(UAYS):

6. CALCULATE COEFF.? N

7 . AVG EKGKD:

$$
\text { CHAN H38 } \quad 13.7900
$$

Q. QUENCH COEFFS $(A, H, C, D)$ :

$$
81.889491,-0.1480533 .0000107 \% .0 .00000304
$$

9. OUENCH LIMITS(LOH,HISH): 39.000000, 282.00000000 